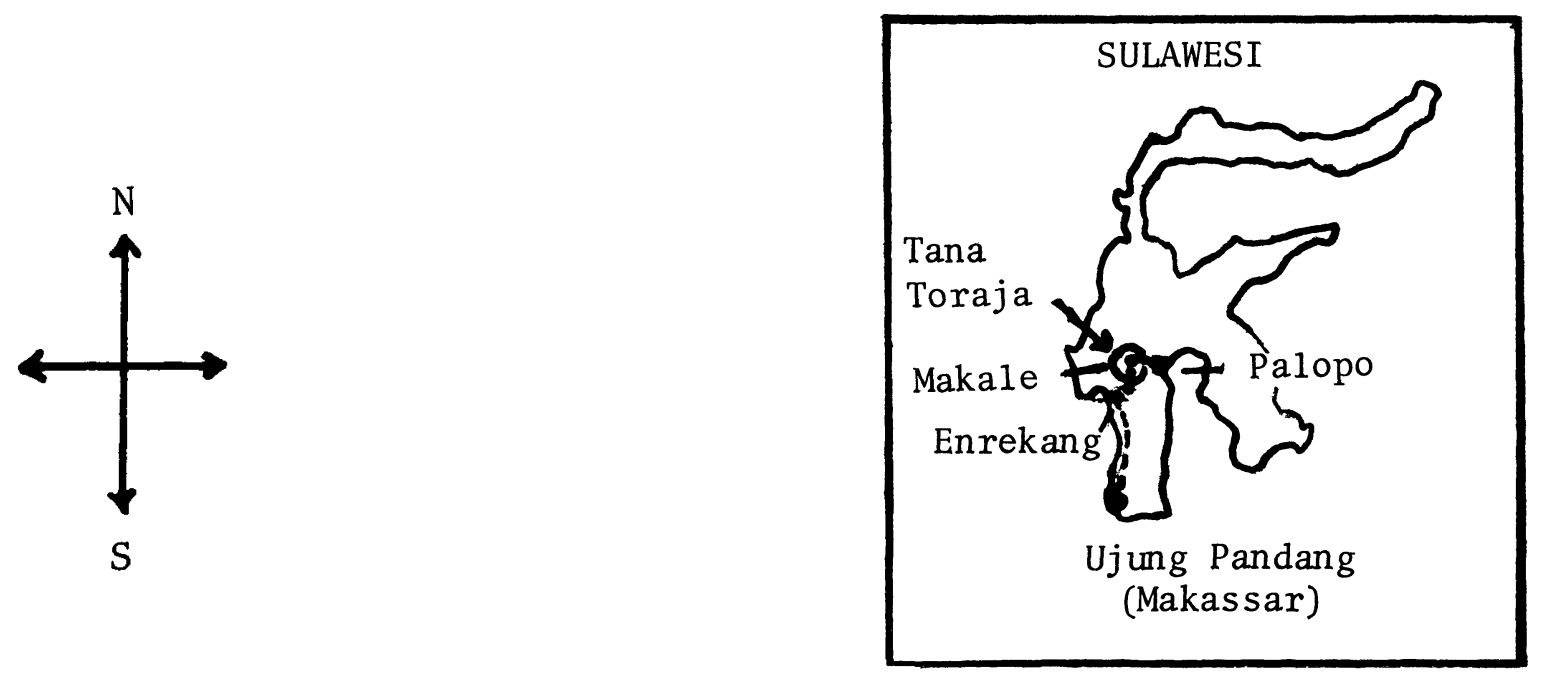

Scale 1:200,000

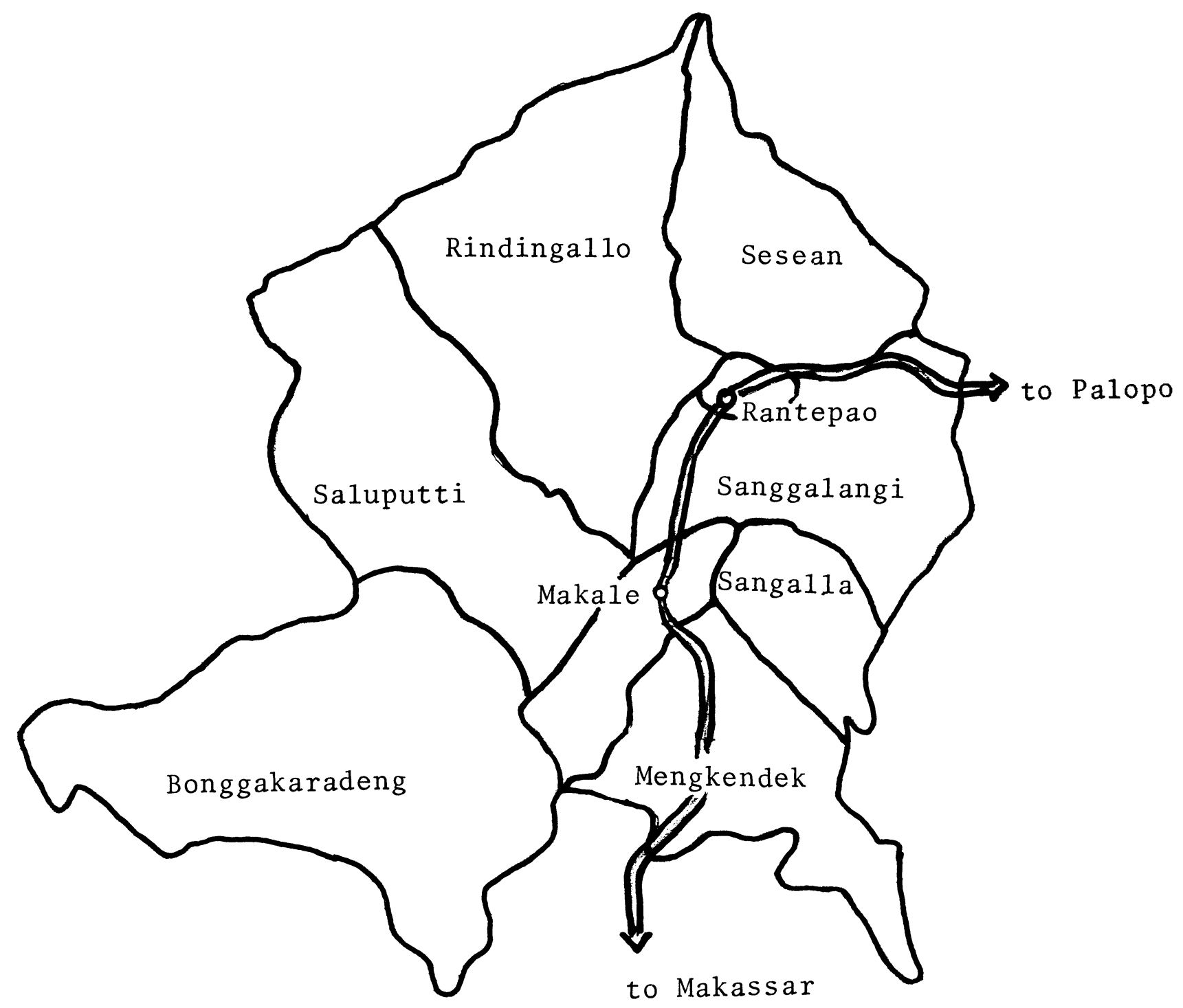




\title{
COOKING POT POLITICS: A TORAJA VILLAGE STUDY*
}

\author{
Eric Crysta1
}

Studies of contemporary society in the eastern regions of the Indonesian archipelago have lagged far beyond analyses of current developments in Java, Bali, and Sumatra. Discussions of entrepreneurial limitation, agricultural stagnation, ethnicity and urbanization in the post-colonial era have generally been limited to the core and western regions of the nation state. Most societies east of the Makassar Strait remain locked into descriptive, largely archaic ethnographic literature of past decades and centuries. This village study emerges from a fundamental curiosity concerning the nature of contemporary culture in regions far removed, in conceptual as well as geographic terms, from the Javanese heartland. Coastal Sumatra, inland Java, densely populated Bali continue to manifest dilemmas of population explosion, agricultural involution, economic dualism and urban expansion due to the impact of external cultural penetration, alien administration, and revolutionary dislocation. What might be the nature of the contemporary political process in a hinterland regency where Islam is absent, indigenous Indonesian religion predominant, Christian evangelism persistent and colonialism hesitant until the dawn of the twentieth century? To what extent do remote eastern archipelago locales follow lines of historical development parallel to those we11 known for Java? Is the fundamental ethnic diversity and cultural heterogeneity of Indonesia reflected in the configuration of contemporary political life in the provinces? Does social change proceed in a manner consonant with local cultural tradition and therefore differentially in regions culturally, ecologically, and demographically distinct from one another?

Stimulated by such questions, field research was begun in Sulawesi early in 1968. Twelve months of work focusing upon urbanization in the highland town of Makale, administrative capital of Tana Toraja Regency, were completed in April 1969. The dissertation which emerged from this field experience focused upon the integral relationship between contemporary urban political 1 ife and traditional ritual and belief systems. After a two-year interregnum further field word was carried out from Ju1y through December 1971; the village perspective was explored during the subsequent term of field investigation in the Makale region. During the brief interim of twenty-four months several important national events with significant local consequences had transpired which strongly suggested a linear analysis of developments in Tana Toraja. The initiation of the Five Year Development Plan, the National Election of July, 1971, the commitment to the development of a local tourist industry had, in sum, effected profound transformations in the political and social fabric of the regency. Ultimately the thrust of the research came to focus upon the persistence of archaic leadership prerogatives within the context of a rapidly changing local political structure.

* Field research in Sulawesi was facilitated by grants from The Southeast Asia Development Advisory Group of The Asia Society (1971) and USPHS Training Grant in Anthropology GM-1224 (1968-69). 
Although this study has very much grown from the social reality as perceived through interviews, written documents and general observations in Tana Toraja, one fundamental preconception must be admitted. In village Indonesia, analyses of the expression of political allegiance, the coalescence of leadership roles, and the structure of status relationships must proceed with reference to the traditional culture matrix. Here in Tana Toraja Regency electoral politics and ancient ritual, tourist promotion and Christian evangelism, public administration and buffalo sacrifice are components of contemporary society comprehensible only upon the assumption that the quintessence of current socio-political dynamics lies deeply emplanted within the enduring structures of tradition.

As a considerable portion of this report treats of religious ritual a note of justification may here be in order. How might the description of rites of an autochthonous Indonesian death cult relate to our desire to describe and comprehend social change on Sulawesi? Some years ago Edmund Leach took exception to the view that ritual pertains exclusively to those actions which transpire in a sacred or religiously charged situation. Writing of northern Burma Leach observed,

The structure which is symbolized in ritual is the system of socially approved "proper" relations between individuals and groups. The individuals who make up society must from time to time be reminded, at least in symbol, of the underlying order that is supposed to guide their social activities. Ritual performances often have this function for the participating group as a whole; they momentarily make explicit what is otherwise a fiction. ${ }^{1}$

Leach takes exception to Durkheim's division of the social world into sacred and profane spheres. Leach's observations concerning the Kachin region of Burma seem particularly applicable in the Toraja highlands of Sulawesi. Here ritual of course engages community energies in the propitiation of supernaturals. More significantly in terms of our present perspective, ritual elicits and reinforces established patterns of authority, status, and power. Leach goes on to "assume that individuals faced with a choice of action will commonly use such choice to gain power, that is to say they will seek recognition as social persons who have power; or to use a different language, they will seek to gain access to office or the esteem of their fellows which may lead them to office." 2

As will soon become clear, the Toraja death ceremony detailed below becomes an arena for the reinforcement of traditional status patterns with the ultimate end of elevating to high electoral office the principal organizer of the great ritual. Ritual in this case functions to reinforce the "underlying order" alluded to by Leach. The relation between traditional culture and contemporary political process in developing areas has of late commanded the attention of a number of writers within the field of anthropology. In an attempt to define the parameters of local-level political inquiry the concept of "political field" has been developed, referring "not necessarily to a closely integrated political system, but (to) a spatial-temporal continuum with 1. Edmund R. Leach, Political Systems of Highland Burma (Boston: Beacon Press,
1954), pp. 15-16.

2. Ibid., p. 10 . 
some systematic features." 3 The authors of Political Anthropology assert that local-level political research comprises "the study of processes in determining and implementing pub1ic goals and in the differential achievement and use of power by members of the group concerned with these goals."4

The political field in Tana Toraja embraces the traditional village as well as contemporary urban 1 ife and includes both ritual performance and regency-1evel development strategy. In a region where the colonial era spanned merely four decades, where indigenous religion continues predominant, and where the prestige and authority of the nobility endure to the present, traditional religious rituals and status relationships color all aspects of contemporary society. In describing the present-day Toraja social environment in terms as much ethnographic as developmental, I have in no way intended to suggest that the Five Year Development Plan, the National Elections, and local contests for village leadership are less real concerns here than elsewhere in Indonesia where traditional culture has been compromised by long-term historical and economic processes. This paper commences with the view that traditional culture can in many ways be reconciled with the imperatives of twentieth-century administration. The Toraja case of an enduring megalithic culture highly integrated within the Indonesian national political system should give pause to those who see in the process of development an inevitable disintegration of traditional values, mores, and beliefs in the direction of rural proletarianization or urban anomie. Those dangers are always present; yet the interface of traditional world view with national political imperatives and economic priorities does not necessarily entail wholesale displacement of traditional culture. The events discussed below give some indication that political development in a modern nation state may not only arrest cultural disintegration, but positively enforce traditional status and belief patterns. Under the proper conditions, set at the loci of national and provincial political power, traditional authority patterns and belief systems are seen to wax renascent under a national administration fully committed to development goals.

\section{Traditional World: Tandung Settlement}

The first crowing of chickens high in treetop roosts signals the beginning of Toraja day. Heavy wooden doors and shutters swing open to the stiliness of predawn morning. The air is moist and cool as the stars ebb before the faint suggestion of dawn. Low clouds envelop the scattered homesteads, cascading rice terraces, and lush bamboo groves of Makale valley. The smoke from a score of kitchen fires wafts upward through thatched roofs melting smoothly into the mists of dawn. High above the valleys now golden with padi, fresh spring water runs strong and clear from rock-1ined wells. Gourd-shell scoop in hand, villagers gingerly follow narrow hillside paths to bathe and draw off fresh water in long bamboo tubes. The spring-fed pool at Buissun is large; bamboo vessels gulp down great draughts of clear liquid with a deep resonance peculiar to these Toraja hilis. The heavy bamboos are borne homeward over the shoulders of barefoot women clad simply in tightly wrapped sarongs knotted about the chest. Fires of dried bamboo soon boil fresh

3. Marc Swartz, Political Anthropology (Chicago: Aldine Publishing Co., 1966), p. 30.

4. Ibid., p. 7. 
water in the kurin (cooking pot); young corn or tubers will be prepared for the perfunctory breakfast that passes for the first meal of day. Tuak wine gathered from beneath the high fronds of the arenga palm often complements boiled maize, sweet potatoes or starchy cassava roots. The granular mist yields but slowly to the warming rays of the sun reaching over the high limestone mountains to the east. With daylight, the heavy calm of first dawn succumbs to the crisp airs of new morning. The ethereal clouds have glazed the leaves of the durian tree, anointed the bamboo thatch, coated the green grasses with heavy dew which refracts brilliantly when pierced by the rays of the rising sun. Under the eaves of a great saddle-shaped roof a large form stirs, then rises laboriously to its feet. Nervously testing his tether, the tedong bonga, the highly valued piebald water buffalo, churns the damp soil underfoot to thick paste. Several pigs grunt noisy impatience at the tardy arrival of their morning swill. Scores of chickens have long since descended to the house courtyard, chancing furtive sorties into kitchen and residence quarters in search of unswept grain from the meal of the previous evening. A small boy unfastens the coarse black leadrope of the buffalo from the granary post to which it has been affixed. Smoothly he gathers up the slack and mounts the animal behind the neck. The two swing down the mountain trail to seek pasture in the stubble of a newly harvested field in the wide valley below. One by one statuesque fighting cocks are carried from kitchen shelter out into the crisp morning air. Positioned to absorb the warmth and strength of the now bright sunshine, the birds will be massaged and tended throughout the long day. They are fed but once, at dusk, and then only with select kernels of dried corn. The cocks often wander the length of a thin restraining cord secured to a stake implanted in the ground. For each bird there is a specific cage of bamboo, plaited in a manner distinct from all others in the household.

Perhaps the finest assemblage of cocks in all Makale is to be found at Tandung settlement, Burake village at the residence of Puang Kepala a few kilometers from the administrative capital of Tana Toraja Regency. According to Puang Kepala, his passion for cockfighting is the result of both personal predilection and family tradition. Wagering large sums on fighting birds was a pastime traditionally followed by the wealthiest and most prestigious inhabitants of the 1 and, the noble caste here referred to by the title Puang. ${ }^{5}$ At Tandung the family heritage of Puang Kepala is evidenced by architectural forms, ongoing social interaction, and food preparation as well as in the continuing attention to cockfighting. Dominating the residence site, overshadowing all other structures at Tandung is the magnificent old rice granary built in precolonial times by the former ruler of Makale, Puang Tondon. With bamboo roof arching high on the north-south axis,

5. The concept of caste employed here conforms to Wester's definition as "a system of rigid social stratification characterized by hereditary status, endogamy, and social barriers sanctioned by custom, law or religion" (Webster's Seventh New Collegiate Dictionary, p. 130). Females of the three principal castes are forbidden to marry down the hierarchy, high caste males are permitted to marry as they wish although the status of their children will be assessed with respect to both maternal and paternal heritage. Death was formerly the sanction applied to high caste women found to be engaged in liaisons with lower caste males. The subject of caste is extremely sensitive in Tana Toraja today; the term kaunan (serf caste) is never uttered in public. Consciousness of birth and ascribed status remains high throughout Tana Toraja, and in most villages the nature of traditional social relations has changed little over the decades. 
the old storehouse continues to function as grain repository, reception hal1, status symbol, and buffalo tethering post. The six pillars supporting the structure mark the storehouse as the possession of a wealthy noble. Traditional architectural forms rigidly proscribed so great a structure to castes other than the nobility. Under the roof can be discerned ukiran Toraja, etched designs in wood which are the unique hallmark of local craftsmen. Once ornamented in yellow, red, b1ack and white, the paints have long since faded before the elements. The deeply incised patterns clearly remain. Between the grain storage compartment and the ground is a substantial wooden platform. Here guests are greeted. Woven reed mats are unrolled to cover the rough wood; the formal reception of visitors transpires according to traditional Toraja etiquette. The place of the Puang is against the southeastern pillar, the one nearest his house. The physical position of others with respect to the nobility is also formally delineated. Thus during a meal served at the storehouse, nobles of similar status will be seated against the granary pillars, often sharing the same mat with their host. Middle caste individuals will also be seated here, though in less desirable (pillarless) positions on the platform. Members of the lowest or traditional serf caste will normally eat squatting on the ground, from time to time being supplied with meat from the plates of the nobles. Such is the traditional nature of social relations in Toraja villages. Great care is taken at Tandung to ensure that the meat of the white buffalo, great river eel and white chicken never enters the cooking pots of the Puang. Such foods are strictly forbidden to the progeny of the mythical high caste ancestor who, descending from the sky, consummated a union with a water sprite from the depths of the river Sa'dan. Puang Kepala refuses to match one of his cocks against an all white adversary as the victor traditionally carries home the leg of the defeated bird. Consuming the meat of a white rooster would be expressly forbidden to members of the noble caste.

Rising from the valley rice fields a small footpath traverses narrow earthen padi dikes before winding up the hillside to the residence of Puang Kepala. The path plunges into thick groves of tallang bamboo (the most commonly used form of bamboo) which mask from view below the several houses at Tandung. One soon encounters along the trail two homes of traditional construction nestled into the side of the hill. The homes are oriented to the north, facing toward the source of the $\mathrm{Sa}$ 'dan river which waters the most fertile rice lands of Tana Toraja. Tomatoes and corn are planted haphazardly about a small household garden. Green beans craw1 determinedly up a trellis of latticed bamboo. A skinny short-haired dog with tail curled sharply forward barks furtively at the approaching stranger from behind sturdy wooden house pillars. Seated on the porch of one of the homes, a middle-aged woman winnows red-grained rice with sure, even flicks of her wrist. At intervals she stops to pour off the cleansed grains into an upright basket. Spitting a mouthful of blood-red betel juice of $f$ the side of her porch, she replenishes the rice in her winnow and proceeds in solitude. The soft, rhythmic swishing of the rice grains filters up towards the top of the hill. The trail soon crests; immediately to the left a sheer precipice drops off to the rice terraces seventy feet below. To one's right appears the rice granary of Puang Kepala and behind it the nondescript, somewhat decrepit residence of the Puang. Immediately ahead some thirty yards down the path is yet another home, the residence of Pong Salapu, faithful retainer of Puang Kepala. The home of Puang Kepala is noteworthy only in its ordinary appearance. A "modern" house walled and roofed completely in bamboo, the ten-year-old structure now leans precariously on the stilts which raise it half a meter 
above the ground. In the immediate vicinity are planted vegetables, papaya, coconut, durian, corn and cassava. Throughout these Toraja lands home sites are dispersed; residence generally is located in close proximity to the ricefields and terraces.

Social Stratification and Religious Integration

The three homes situated on the approaches to the residence of Puang Kepala are inhabited by individuals of unique social standing. All are members of the serf or Kaunan caste. Their fathers had been brought here before them by the Puang of Makale, Puang Tondon, at the time the large granary was constructed. In the waning days of the nineteenth century the rule of the strongest prevailed throughout Tana Toraja. Puang Tondon resided permanently atop a fortified mountain some three kilometers to the east. Although universally recognized as the ranking noble of the valley, his authority was often challenged. Warring factions seemed to continually disturb the tranquillity of the land. Never amalgamated under a state system, the Toraja highlands were fragmented into myriad fiefdoms with ruling princes continually competing for military supremacy and economic dominance. Internecine quarrels among the Puang aside, great tension was often expressed between the nobility and the middle caste, To makaka, of local society. The latter were often powerful and wealthy, thought to be descendants of the pioneer cultivators of these lands. Local myth presaged the subsequent arrival of the Puang caste and its institutionalization of new status relationships at the expense of the To makaka. The three castes, Kaunan (serfs), To makaka (freemen, by far the most numerous), and Puang (nobles, both male and female) were thus sharply defined. Relationships between nobles and freemen were often hostile. Such hostility was manifest at the time Puang Tondon entered the Burake village region with an armed force to quell an affront to his authority initiated by entrenched village leaders of the To makaka group. The battle was soon joined and in the end the Puang was victorious. As a prize of war Puang Tondon appropriated a number of choice padi fields from his vanquished adversaries. In commemoration of the establishment of noble control the Puang ordered that a large rice granary be raised at Tandung. A small home was also built there to quarter the Puang when he deigned to reside in Burake to oversee the planting the harvesting of his holdings there.

The Puang now summoned from nearby villages a number of his ancestral servants, the so-called Kaunan bulaan (golden serfs) who traditionally served the noble family. These were instructed to move from the Mengkendek district to Makale. The Kaunan bulaan had no need to erect individual rice granaries; their sustenance was to be dispensed from the great storehouse of the Puang. Without personal landholdings, their labor would be invested in the fields of Puang Tondon; after the harvest the Puang would reward his servants with a portion of the newly reaped grain. The daughters of these serfs would be placed in the domestic employ of the Puang, their sons would tend his buffalo, preen his fighting cocks, and work' his fields and gardens. Among the several traditional categories of serfs which obtain in Tana Toraja, the Kaunan bulaan were distinguished by the intimacy of their relationships with their lords, by the unique trust which the puang placed in them. Shortly after birth, an infant noble would be handed to a female Kaunan bulaan who would nurse the young baby until the mother's milk began to flow. Sometimes the care and raising of a young noble child would for years be the responsibility of trusted royal servants. Offerings to 
the ancestors of the nobility would be entrusted to the "golden" serfs. Preparation of the food and drink of the Puang would similarly be the exclusive responsibility of this group. The close ties between Puang and Kaunan bulaan are clearly demonstrated with reference to the rigidly enforced food taboos of the nobility. All restrictions upon the meat of white buffaloes or the flesh of river eels and others adhered to by the nobles applied equally to their Kaunan bulaan. If a noble were proscribed from eating the meat of a white chicken, so his royal serfs would be similarly enjoined. Because they were bound by the same dietary restrictions, the serfs of the Puang could be delegated the intimate tasks of wet nurse, royal cook, and ritual surrogate.

During pre-colonial times the rather severe caste lines which characterized Toraja society were complemented by intense territorial fragmentation. Although head-taking was never as assiduously pursued here as in Central Sulawesi, desultory raiding and intermittent warfare inevitably overshadowed local political relations. Travel over great distances was a dangerous, often fearful undertaking. Attachment to village and region remains strong today in Tana Toraja, especially since local ramages are tied to specific ancestral house sites. Often al1 physical remains of these tongkonan (Toraja family house from which a particular ramage is said to have originated) homes have long turned to dust, yet reference is often made to them in the tracing of kin ties. If social stratification and physical dispersion tended to segment local society, what functioned to unite widely scattered households in one common culture system? Great ceremonies of death and burial with intense competition in the reciprocal slaughter of animal domesticates unified village communities and dispersed kindreds at important ceremonial occasions. Underlying funerary and other large ceremonies, the shared religious tradition of Tana Toraja bound all together in common belief and practice. Termed Aluk To Dolo (literally, "ceremonies of the ancestors," general term for Toraja religion), the complex and often gradiose religious rites involved great material as well as spiritual commitment from all members of the community.

After the colonial intrusion in 1906 the religious bond was weakened with Protestant, Catholic, and Muslim missionary efforts yielding ever greater numbers of converts during the first four decades of foreign rule. Yet, ancestral aluk heritage was never completely submerged by the conversion of significant segments of the population to new faiths associated with the ideals of modernism and progress. Familiarity with traditional religious beliefs and participation in aluk religious ritual remains almost universal among all segments of the contemporary Toraja population.

The religious diversity characteristic of present-day Toraja society is expressed in the predilections of the several households resident at Tandung. The family of Pong Sabena, whose house is first encountered on the pathway up from the fields, is Catholic. His neighbor Ndo' Pasa', who buys padi from farmers and sells winnowed rice in the marketplace, is a Muslim. Pong Salapu alone remains in the faith of his ancestors although most members of his family have converted to a rather obscure Protestant sect. Puang Kepala classifies himself a Protestant although he was baptized and educated in Catholic primary schools and continues to sacrifice to deata spirits (supernatural being most usually associated with agricultural rituals) and deceased ancestors at crucial planting and harvest times of the year. Despite the heterogeneous religious affiliations which obtain in the Toraja region local social interaction up to the present time remains anchored in 
adat (customary 1aw) practices and traditional beliefs. The most important events, the greatest ritual occasions, the most memorable family gatherings are the traditional funerals which summon forth commitments and obligations transcending contemporary religious affiliations, political loyalties, or caste identities. The demands of economic reciprocity and familial prestige here burden farmers and wage earners alike with debts of pigs and water buffalo perhaps inconsonant with the spirit of development in present-day Indonesia. The wholesale removal of children from school, bureaucrats from office, and farmers from field to ceremonial center for days of uncomfortable sojourn in makeshift bamboo shelters may be dysfunctional in an age where the dispatch of a condolence card might suffice. No matter in Tana Toraja. Social life here is founded upon the premise that ritually prescribed economic reciprocity forms the basis of most status relationships; active participation in death festivals is the sine qua non of social responsibility in local society.

Toraja Funeral, Belief and Ritual

The Tandung community last witnessed a great funeral in November 1968. The passing of Puang Pantan, the grandfather of Puang Kepala, stimulated large-scale planning for the death ceremony to follow. Toraja tradition sets no limitation on the interregnum between death and burial. Indeed, often the greater the eventual funeral the longer the hiatus between expiration of the deceased and the commencement of ritual activities culminating in burial. Puang Pantan was the 1ast of a group of siblings (including his elder brother, Puang Tondon) who once maintained supreme authority in the three southern districts of Tana Toraja. These lands were the province of the nobility, the areas of Tana Toraja where exclusive political control rested firmly in the hands of the small endogamous nobility. Puang Pantan had been an adolescent when Dutch military forces pushed into Makale from the southeast in 1906-7. He had lived for some years in the Bugis regions to the south where he had accommodated himself to local custom by converting to Islam. Nevertheless, upon his return to his native lands he reverted to the ancestral beliefs of Aluk To Dolo, a commitment maintained until his death in early 1968.

Located on a hillock perhaps three kilometers north of Tandung, the pillared home of Puang Tantan rises on high ground enveloped by small rice terraces. Half a mile below are the large family sawah situated on the banks of the $\mathrm{Sa}$ 'dan river. Across the great waterway is the most important of these rice-producing lands, the uma pa'puangan (sawah of the nobility). This padi field is planted with the special strain of rice termed pare kasalze (the great rice plant), reserved exclusively for offerings to the spirits of the land. At the death of Puang Pantan, his children and grandchildren assembled from miles around to lay plans for the death festival. The organization of such an event is no mean task. In the case of a Puang of power and wealth the ceremony of death requires two separate rituals, one of five days' duration and the second (following the intervening agricultural year) comprising seven days and culminating with the burial. The ultimate disposal of the private landholdings of the deceased is determined relative to the contributions of his children to the death ceremony. During activities preparatory to the burial the body remains in the residence where it is wrapped in many layers of cotton cloth. An attempt is thus made to insulate the corpse from the external elements, yet the inexorable process of decay must take its natural course. 
Should sirih be offered to guests, a symbolic amount is placed by the head of the deceased. At night a lamp is 1 it for the dead person. Symbolic food offerings are proffered when family members partake of their common repasts. The fact of death is formally ignored; polite reference is made to the "sick" or "sleeping one." The bombo (soul) remains in the immediate vicinity of the body and cannot be dispatched to the land of souls, puya, until all the long and complicated steps in the rigidly prescribed death ritual are carried out. The unpleasant odor which in the first weeks pervades the house is studiously ignored. Care is taken that parasites do not infest the cadaver.

In the traditional Toraja world there are several specialists who concern themselves with matters of death. The to mapulzi in former times was assigned the task of warding off maggots which often appeared from within the wrapped body, supposedly carrying off miniscule portions of the deceased to lairs beneath the earth. Another specialist, the to maparandan, most often a close relative of the dead person, remains by the body at all times, providing for it during the course of the ceremony. The most important practitioner in these matters is the to mebalun (the man who wraps), who is entrusted with full responsibility for the proper execution of religious rituals and offerings designed to speed the soul from the village compound to the land of the deceased. The office of to mapulli has of late fallen into disuse. But the to mebalun, often referred to as the priest of death, remains an important officiant at traditional funerary events. In Burake village the old and wizened $\mathrm{Ne}$ Sule has long occupied this position. Upon news of the death of Puang Pantan it was Ne Sule who readied a thin golden needle-the instrument reserved for the binding of the heavy body shrouds of a high-born noble. Summoned to the home of Puang Pantan, Ne Sule mounted the steps to the living quarters. Only at such times is the to mebalun allowed into the residence of others--his passage through the portals of a house is a sure sign of death. The wrapping of the body, binding the frail corpse of the aged Puang in many meters of cloth so as to absorb the body juices and minimize the unpleasantness of decay, was carried out under the close supervision of the to mebalun. The deceased remained for several months in his house while his progeny carefully computed the costs of the great funeral which was to follow.

The ritual demands of AZuk To Mate (ceremonies for the dead) are highly systematized. Funerals may entail one, three, five, and seven day rituals with the most elaborate type consisting of a five day preliminary rite followed months later by a final seven day funeral. Economic considerations are paramount in the selection of the ceremonial schedule. The longer the event the more elaborate the requisite preparations, the greater the burden upon the planners, the higher the ultimate prestige which accrues to the family of the deceased at the successful conclusion of the funeral. At the largest ceremony a minimum of twelve water buffalo must be slaughtered, according to the rules of aluk. Yet between the edicts of religious prescription and the imperatives of social prestige and economic reciprocity a great disparity often occurs. Today a ceremony at which twelve water buffalo are offered is considered large, but not remarkable in terms of the distribution of meat. The earliest Dutch administrators in Tana Toraja estimated the population in the first decade of this century at about $55,000.6$ Since that time the local population has spurted to 300,000

6. From an estimated total of 54,647 in 1926 (E. A. J. Nobele, "Memorie van overgave betreffende de onderafdeeling Makale," Tijdschrift voor Indische Taal-, Land-, 


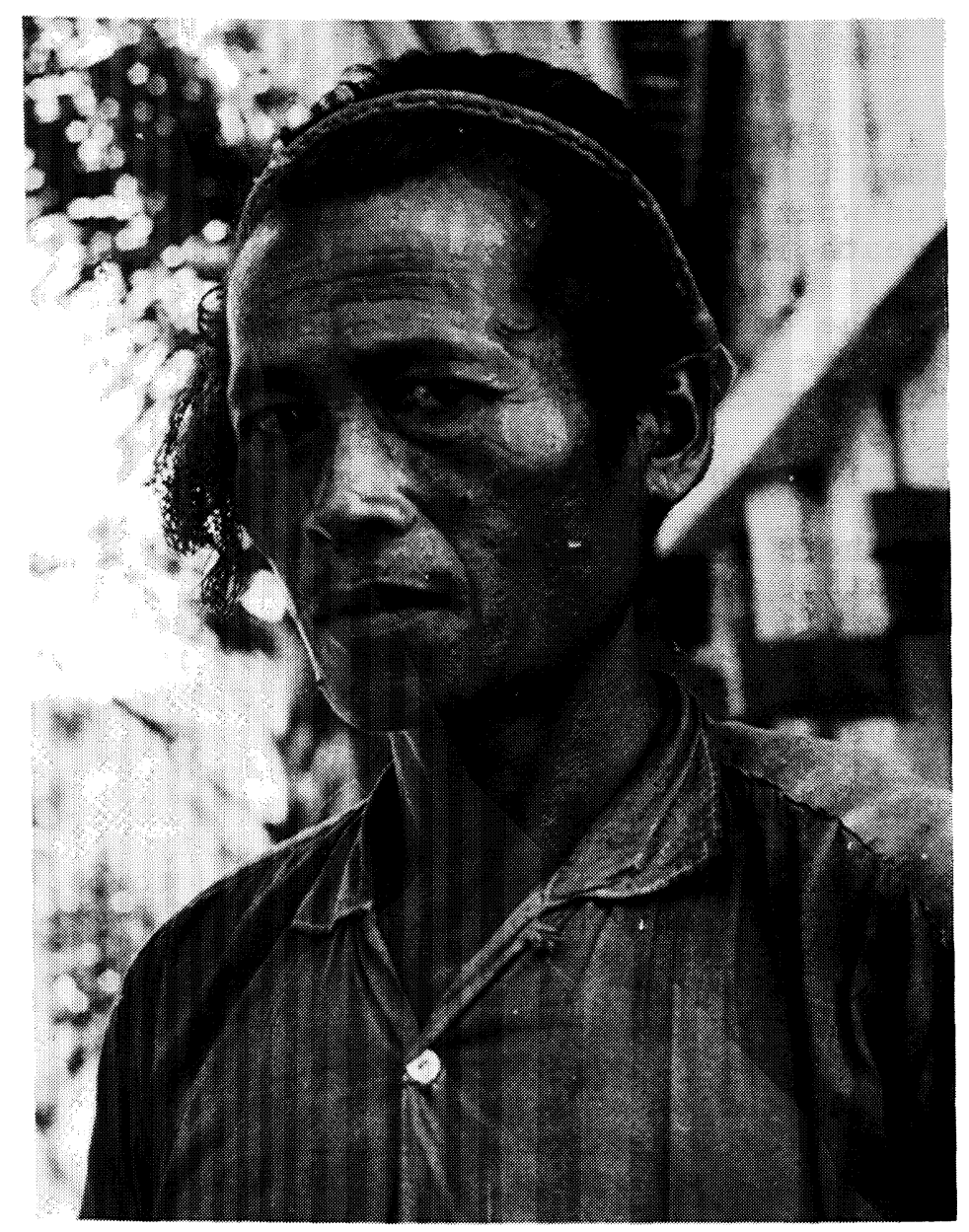

A "golden serf" of the late Puang Pantan wearing the pote tassled headband of mourning. Headband indicates abstention from rice for duration of funeral.

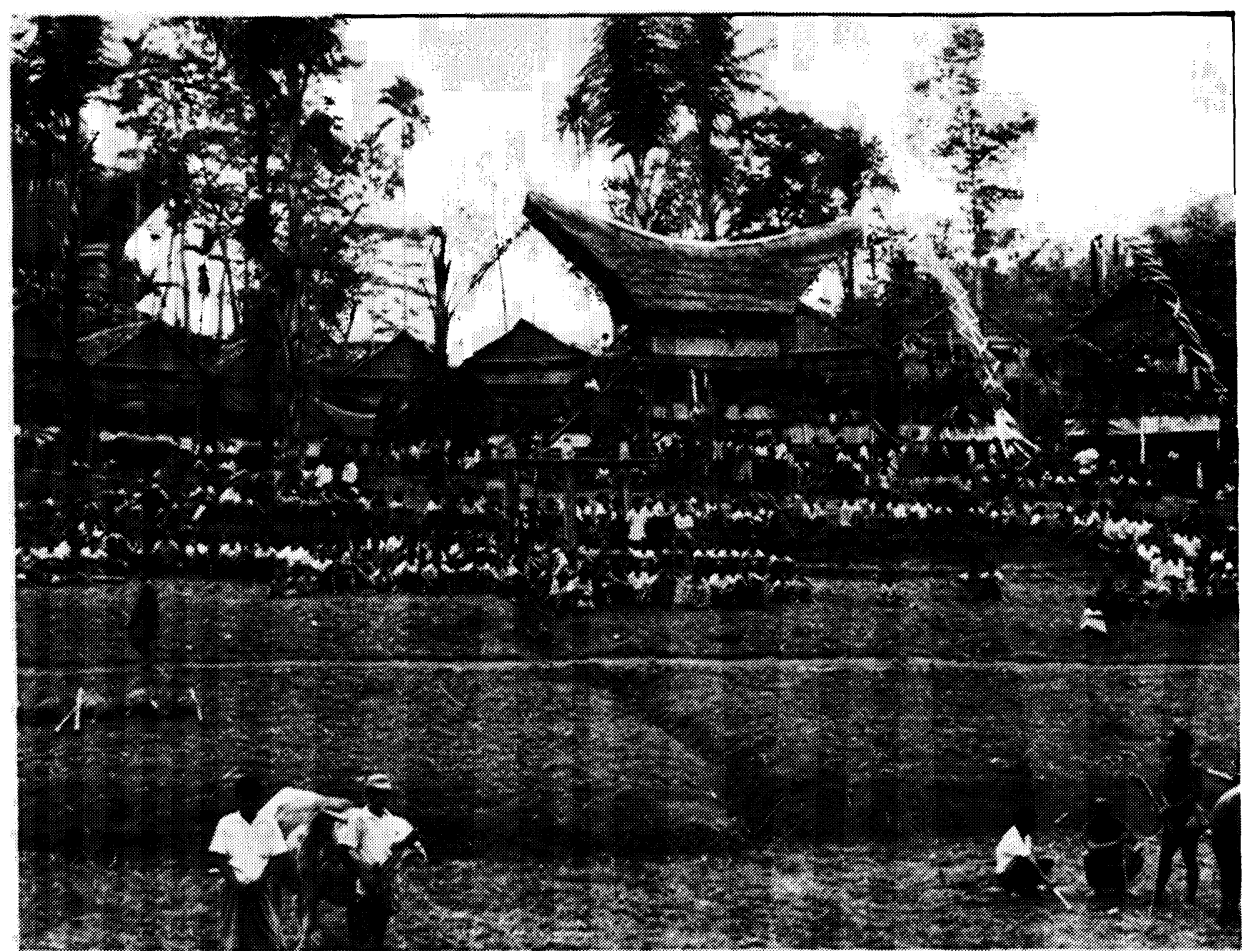

Pantan ceremonial site, Nov. 1968. In upper left is the home of the late Puang Pantan. Large structure in center (with ramp) houses the body of the deceased. Other structures are temporary lantang which house close relatives. Pigs (center left) and water buffalo are displayed by village delegations before slaughter. 
within Tana Toraja with perhaps 40,000 locally born Toraja residing elsewhere beyond the regency borders. In the wake of this population explosion death ceremonies have grown increasingly costly. The pressure of demographic expansion is felt as keenly in the ceremonial as in the agricultural sphere of community endeavor. In order to feed and shelter the thousands of guests expected at the apogee of the Pantan festival a large ceremonial ground would be constructed, many kilograms of rice and coffee purchased, and an ample supply of fresh meat secured.

The cost of raising a great ceremonial center, summoning dancers and ritual specialists, provisioning guests of family and government was extremely heavy. Scores of pigs were slaughtered in the preparation of the ceremonial field alone, hundreds of kilograms of rice were utilized in the feeding of guests, fifty-one water buffalo were killed by the conclusion of the rite. The apex of the ceremonial ground was a graceful bamboo structure with saddle-shaped roof thatched with alang-alang (tall grass). From both ends of the roof floated streamers of white cloth. Underneath the roof a platform of split bamboo was affixed to the large bamboo pillars with thin green lashings. Here the body of the deceased would come to rest after being borne in procession about the borders of the settlement. Curving about the lakkean (structure built to house the body of the deceased during a major death ritua1) just described was a great semicircle of bamboo-walled shelters ( lantang), the temporary dwelling units constructed by villagers from surrounding communities for use by principal relatives of the deceased during the seven days of the death ceremony. Each structure was twostoried, roofed with nipa palm thatch purchased at the port of Palopo, walled and floored with large bamboos cut in the groves of Makale. The ceremonial ground rose, over a period of months, on dry terraces still littered with the stubble of last year's harvest, overshadowed by the large wooden house where the body of Puang Pantan reposed. The body, long since desiccated, remained with its head faced towards the west (a normal orientation for sleeping). Taking the place of his late father as household head at Pantan was Puang Mangura, now responsible for the fulfillment of ritual obligations to the deceased. As his father Puang Pantan before him, the grey-haired Puang Mangura remained steadfast within the fold of traditional Toraja 1 ife-style and religion. His dishes and cups were rigidly segregated from utensils of others, even those of his immediate family. The utensils of the Puang were never to be defiled by the usage of lower status individuals. Should he partake of food and drink far from home, a green bamboo would serve as his cup, the underside of a fresh banana leaf as his plate. Seated under the old rice granary of his late father, often with a huge mug of tuak in hand, Puang Mangura could peruse the pace of construction going on all about him. The lantang shelters were nearly complete, the lakkean to house the body was beginning to take shape, the central kitchen and guest reception stands were under construction. A noted wood carver from Sangalla district was summoned to Pantan to fell an aged nangka fruit tree. From this the arms and legs, torso and head of a wooden man, a three-dimensional facsimile of Puang Pantan would slowly take shape under the steady hand of the craftsman. When finished this statue or tau tau (1ittle man) would remain inseparable from

en Volkenkunde, LXVI [1926], p. 4) the population of Tana Toraja grew in 1944 to 210,000 (J. M. van Lijf, "Tana Toradja 1905-50," Indonesië, VI, No. 6 [1952], p. 258). The 1961 census indicated a population of 275,459 in the regency and most recent 1971 figures from the Regency office place the population total at about 306,000 . 
the body of the deceased during the ritual. Puang Mangura amused himself by whittling the trunk of a one-stringed musical instrument from a length of nangka wood discarded by the carver. During the long nights of the funeral to come the mournful strains of this instrument would be heard accompanying the ancient songs of bereavement and grief performed at death ceremonies. In time the festival ground stood in readiness, the commencement of the funeral itself was at hand. Two matched drums of wood and buffalo hide were hung under the house at Pantan. In the golden sun of late afternoon a water buffalo was led to the western side of the house, its head oriented south towards the 1 and of souls. The throat was stroked softly by the impassive butcher with his left hand as he extracted his sword from wooden scabbard with his right. Gathering the slack from the lead rope, the butcher raised his blade high and swiftly brought it slashing into the exposed neck of the animal. Death came with a heavy thud fast upon the gurgling of fresh blood from the exposed jugular. Following upon the ritual killing of the first buffalo, each successive day until burial was to see the provision of the soul of the deceased with the flesh of a freshly killed domesticate. The body now was turned on its axis so as to be facing south towards puya, the land of the souls. Death, previously ignored in formal terms, was now recognized by a11. The subsequent funeral ritual was designed to enhance the movement of the soul of the departed. A series of steps would be taken, each removing both body and everpresent soul further and further from the family residence until at last burial and its ritual aftermath signaled the freeing of the soul from the confines of home village and the world of the 1iving. In brief these steps involved the completion of the tau tau statue and the laying of it beside the body inside the house. After an interval of several days the body was wrapped again and an outer layer of red cloth was affixed. In procession the statue and body were transported from residence to nearby rice granary where they remained for several nights. Three days later led by dancers adorned with buffalo horn headdresses, wooden statue and wrapped body adorned with gold leaf were carried about the village borders. The deceased was in time returned to the ceremonial site and placed atop the high lakkean structure built specially for this purpose. The body reposed for over a week here until the slaughter of pigs and water buffalo was past and the guests had departed for their own homes. Since the late Puang Pantan had been preceded in death by his wife, the formal role of principal mourner was enacted by the eldest son of the deceased, Puang Mangura. As the body was moved to the granary the principal surviving son followed in the procession. It would be his task to sleep beside the body at night, to provide it with food and sirih at appointed times during the day.

\section{Cooking Pot Politics}

Strong as the commitment of Puang Mangura was to all aspects of the Pantan funerary rite, his deep emotional involvement predicated that responsibility for the inevitable financial arrangements, social strategies and political compromises of the funeral fall to others. Principal direction of the temporal aspects of the event was assumed by the son of Puang Mangura, Puang Kepala of Tandung. As government official and scion of the Makale nobility, the choice of Puang Kepala was confirmed both by traditional practice and contemporary conventional wisdom. The solicitation of funds from close relatives, purchase of supplies from as far away as $\mathrm{Palopo}$ and Makassar, assignment of 1 antang shelters, and negotiations with government officials became the ultimate responsibility of Puang Kepala. Under his direction the several 
Puang Mangura massages his prize fighting cock at Pantan ceremonial site. The body of his father, the late Puang Pantan, reposes on rice granary platform in background.
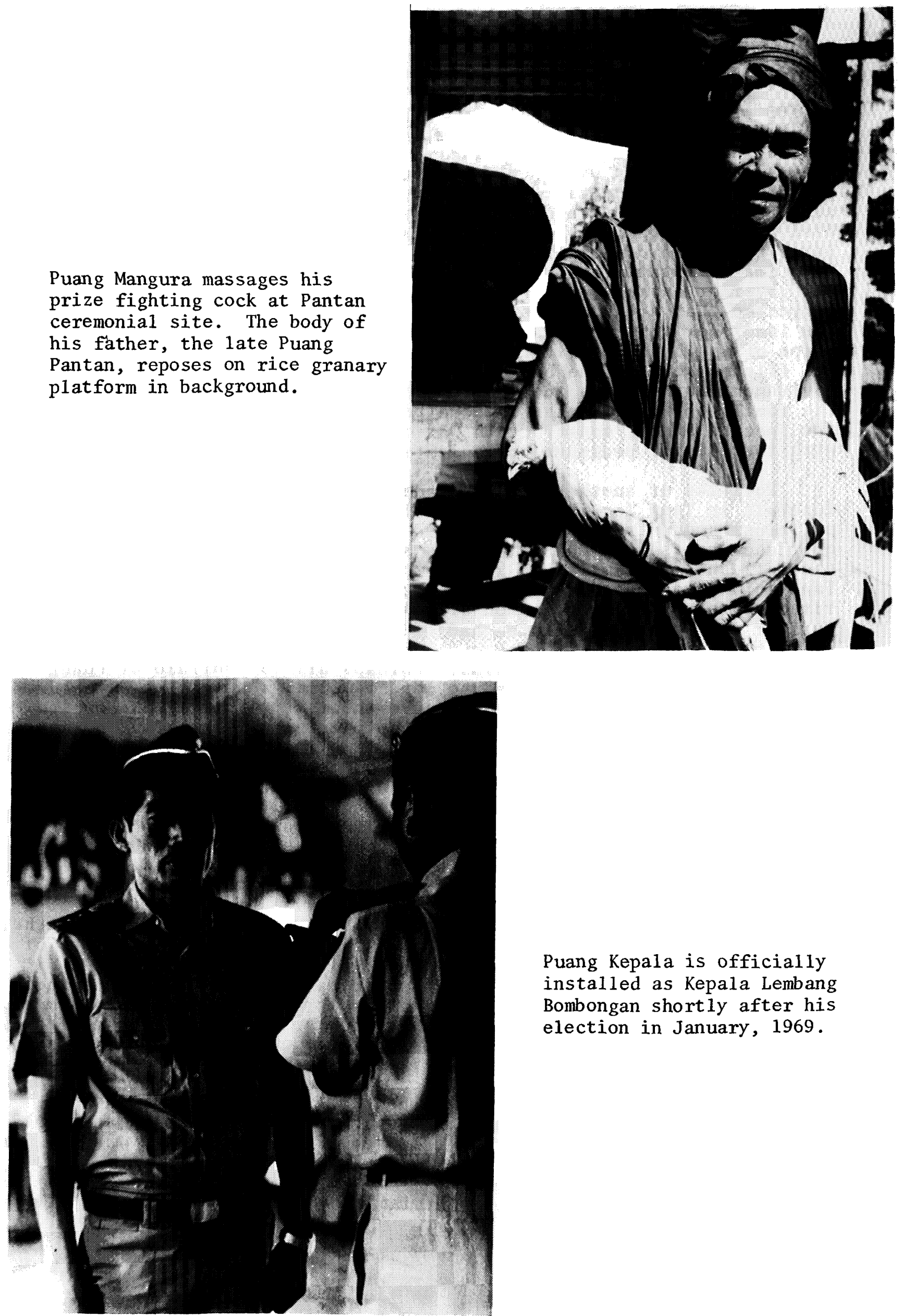

Puang Kepala is officially installed as Kepala Lembang Bombongan shortly after his election in January, 1969. 
score lantang shelters had been built by unpaid village labor. Territorial groups traditionally governed by the Puang of old were summoned on the basis of ancient feudal obligations to their lord, asked to bring not only their skills and talents but considerable quantities of bamboo and other building materials. Each group of participating villagers was provided with a midday meal of freshly cooked pork and rice, plied with betel and cigarettes by the family of the late Puang. So also political relations with the government in Makale town were handled by Puang Kepala. The regency government planned to receive a large number of official guests at the Pantan rite, specifically the Panglima (military commander) of Sulawesi Selatan province and perhaps the governor as well. To this end the government of the regency had suggested that a large guest platform-reviewing stand be constructed. The labor for this non-traditional edifice was "recruited" from the corps of wajib lapor (1iterally, "forced to report"); these were rank and file members of the banned Barisan Tani Indonesia ${ }^{7}$ now obligated by government authorities to report for a day's corvee labor each week. The family of Puang Pantan acceded to suggestions for the building of the special stand; construction was initiated by individuals associated with the defunct peasants' organization.

Politics of another kind pervaded this ritual event as it does all funerals in Tana Toraja. This so-called politik kurin (cooking pot politics) accounts for the continued vigor and ever more costly nature of these events. To maintain one's status in the community, to sustain the influence of family and $k$ in in the countryside, it is imperative in Tana Toraja to engage in the reciprocal slaughter of domesticates at ritual events, the most common of which are funerals. If twenty years earlier the late Puang Pantan had offered a water buffalo to the family of Puang Tarongko, then now Puang Tarongko would be obligated to repay the debt, to reciprocate in kind. Perhaps all the buffalo of Puang Tarongko had succumbed to disease, or his family had fallen on hard times. All efforts would be made nevertheless to fulfill the obligation even if the sacrifice entailed the pawning of sawah 1 and or perhaps the sale of heirloom jewelry. In some instances repayment is practically impossible due to economic hardship; in such cases individuals so handicapped would not attend the ritual--much to their own chagrin and shame. This reciprocal system involves not only the nobles of the land but the To makaka as well--indeed all men in possession of personal wealth which can be changed into the social currency of a large pig or water buffalo to be slaughtered at a death festival. When the deceased is borne in procession about the ceremonial ground and emplaced atop the lakkean structure, the arrival of guests in great numbers commences. Individuals trave1 in territorial groups and gather some distance from the festival site with their tuak wine, baskets of cooked rice, shoulder-loads of firewood, pressure lanterns, live trussed pigs and huge water buffalo to prepare formal entry into the funerary grounds. A large bamboo gong is struck solidly with a hammer of wood announcing the arrival of a particular group of guests. They enter with water buffaloes in the lead, followed by pigs and the rest, circling round the ceremonial site in a display of wealth and prosperity designed to impress all assembled. Later in the afternoon, a number of buffalo will be led into the central field to engage in unrehearsed, impromptu combat. The owners of buffaloes and pigs seek out individual family members of the deceased. The animals they have

7. The Indonesian Peasants Party--a communist, PKI-affiliated group, illegal since 1965. 
brought will be proffered to the grieving relatives. But a question of acceptance always remains. Offering an animal is not entirely a matter of selfless largesse on the part of the giver. Acceptance means the incursion of a major debt. It is true that the more pigs and buffaloes are accepted the greater the amount of meat for subsequent distribution and the higher esteem the family of the deceased will garner in the eyes of village folk. But one must consider also the years and decades to come. In accepting many domesticates, in receiving five buffaloes and twenty pigs, an individual incurs the obligation of repayment; he willingly signs his freedom of economic activity away to the heavy obligations future death rites must inevitably bring. The intricate working of this system of debts and obligations is influenced by yet another factor. The immediate relatives who stage the festival are responsible for the provision of all guests with meat. But if all are provided for, if all ritual needs are similarly fulfilled, some of the buffaloes received may be dipatarru tuo--led straight away alive. The tantalizing possibility of profit thus enters into the affair. Quite possibly a clever man might conclude a large funeral on the plus side, with more buffaloes than when he started, with a number of cows who in years to come might further enhance his holdings.

The politics of the cooking pot continue to dominate local social $1 \mathrm{ife}$, much as they have for centuries. However, the six-fold rise in population and the opening of the Toraja area to external influences have greatly affected the manner if not the form of status competition. The purchase of fancy cakes, fine china, store-bought cigarettes, and gas pressure lanterns in Makassar has become increasingly mandatory for those staging a large death rite. Higher population means that the meat and rice required to feed those attending the rite must be multiplied greatly from the pre-colonial norm three generations past. Many village people now have sons and daughters, sisters and brothers who are wage earners either in the two Toraja towns of Makale and Rantepao, in Makassar or elsewhere in Indonesia. These earned wages are very often returned to the kampung where they are invested in sawah 1 ands and buffalo holdings, in the construction of fine wooden houses or in the staging of large funeral ceremonies. Economic competition has thus sharpened over recent decades as educational opportunities have been exploited by members of the To makaka caste as a means of enhancing economic position and social prestige. It is no matter that wage earners faithfully attend church on Sundays. On the occasion of a great funeral, soldiers from West Irian, bureaucrats. from South Sumatra, teachers from Java and civil servants from Makassar invariably will return on leave to the Toraja homeland to participate in adat family events. The vast majority of these people will eventually retire to their native villages; their economic sacrifices today are designed to ensure a position of status and respect, of wealth and importance among their peers upon their final return on the morrow. The question of tedong, of water buffalo, in terms of debts and obligations, dominates Toraja social life both in village and town, among Christian and traditionalist, obsessing even Toraja students in The Netherlands and the United States.

As a consummate dilettante of cooking pot politics, Puang Kepala naturally used both his family position and status as organizer of the Pantan funeral to advantage in the ongoing competition for prestige. As a prominent noble, community expectations weighed particularly heavy upon him. In his strategically placed lantang shelter, Puang Kepala and his family had for three months prior to the commencement of ritual activities overseen construction in progress, computed the buffalo and 
pigs required to feed the thousands of guests, and gauged the possibilities and dangers of accepting domesticates from the many people known to be contemplating offers. Puang Kepala knew full well the individuals most closely indebted to him, knew also of several wealthy men who even now were tending the bodies of recently deceased loved ones, whose offer of a pig or carabao at Pantan was predicated upon the almost immediate repayment in kind at the soon to be scheduled death ceremony in their home village. Aside from his personal involvement in the give and take of buffalo, Puang Kepala evidenced a yet greater and more ambitious interest in the accrual of prestige. Since 1965 the Toraja Regency had continually postponed Desa Gaya Baru (New Style Village) elections. The coup of September 30 th and the uncertainty and disorganization which followed had dampened enthusiasm for local politics. Now that former President Sukarno had been displaced and President Suharto formally confirmed in his position, the time seemed promising for the reorganization of village structure and the direct election of village chiefs. In the years since the coup of 1965 a steady weakening of political parties and consonant strengthening of political forces allied closely to the army was coalescing throughout Indonesia. ${ }^{8}$ Such trends were as apparent in Tana Toraja as elsewhere in the archipelago. In the context of the political flux of 1968 the Toraja elections were scheduled to transpire, to be preceded by a census and a redefinition of village boundaries. The involvement of Puang Kepala in these events was occasioned by the decision of close relatives prominent in government and army affairs that the hour was propitious for an electoral strike at the political party which for nearly twenty years had monopolized political control of the regency. The precise date of the election had not yet been set in November 1968 as the festival at Pantan was underway, yet its occurrence was certain within a few short months. Puang Kepala was well aware of the fact that his material largesse and traditional leadership role at the Pantan death festival would be an important factor in the success of his candidacy in the upcoming election. The question of munificence was crucial here, because a man's prestige in Tana Toraja is gauged not only in terms of personal wealth or ancestral genealogy but also in the way family fortune and penaa mezo (good heart) are related to the community at large. The time for the expression of such good will is precisely and properly the occasion of a death ceremony. Would the thousands of guests arriving at the Pantan funeral later complain that their rice had been flavored with only the smallest pieces of meat, would they comment that hot coffee and deppa (cookies or cakes made from rice flour and palm sugar) cakes were in as short supply as a sheltering roof during the long nights? Would mourners later observe that the rules of aluk had been neglected, that the traditional order of events had been disrupted, that the rightful wages of dancers, artisans and the To mebalun had been forsaken due to the greed and avarice of the family of the deceased? Such issues are discussed for years subsequent to an important funerary ritual. The seven days of ritual splendor are relived again and again; comparison with other such events of years past is inevitable. Puang

8. A recent analysis of "Military Politics Under Indonesia's New Order" in the journal, Pacific Affairs, by Harold Crouch traces the steady assumption of political power by the military under the Suharto regime. Crouch assesses the army's attitude towards the parties as follows: "While the parties would be permitted to function, there was no question of giving them a greater share of real power. Their autonomy and potential were steadily undermined, leading to the debacle they experienced in the 1971 elections." (Pacific Affairs, XLV, No. 2 [Summer 1972], p. 212.) 


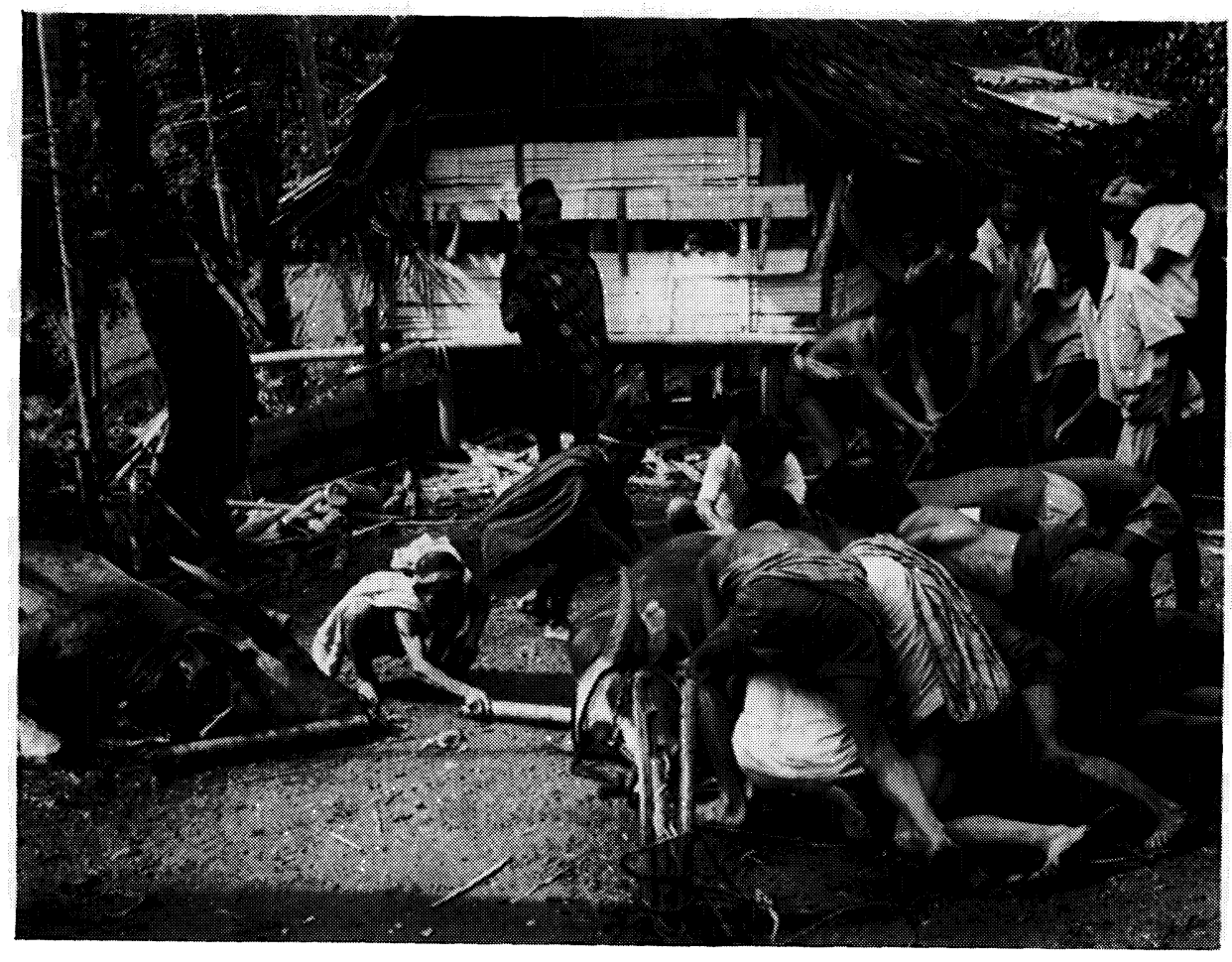

Collecting blood from dead and dying water buffalo.

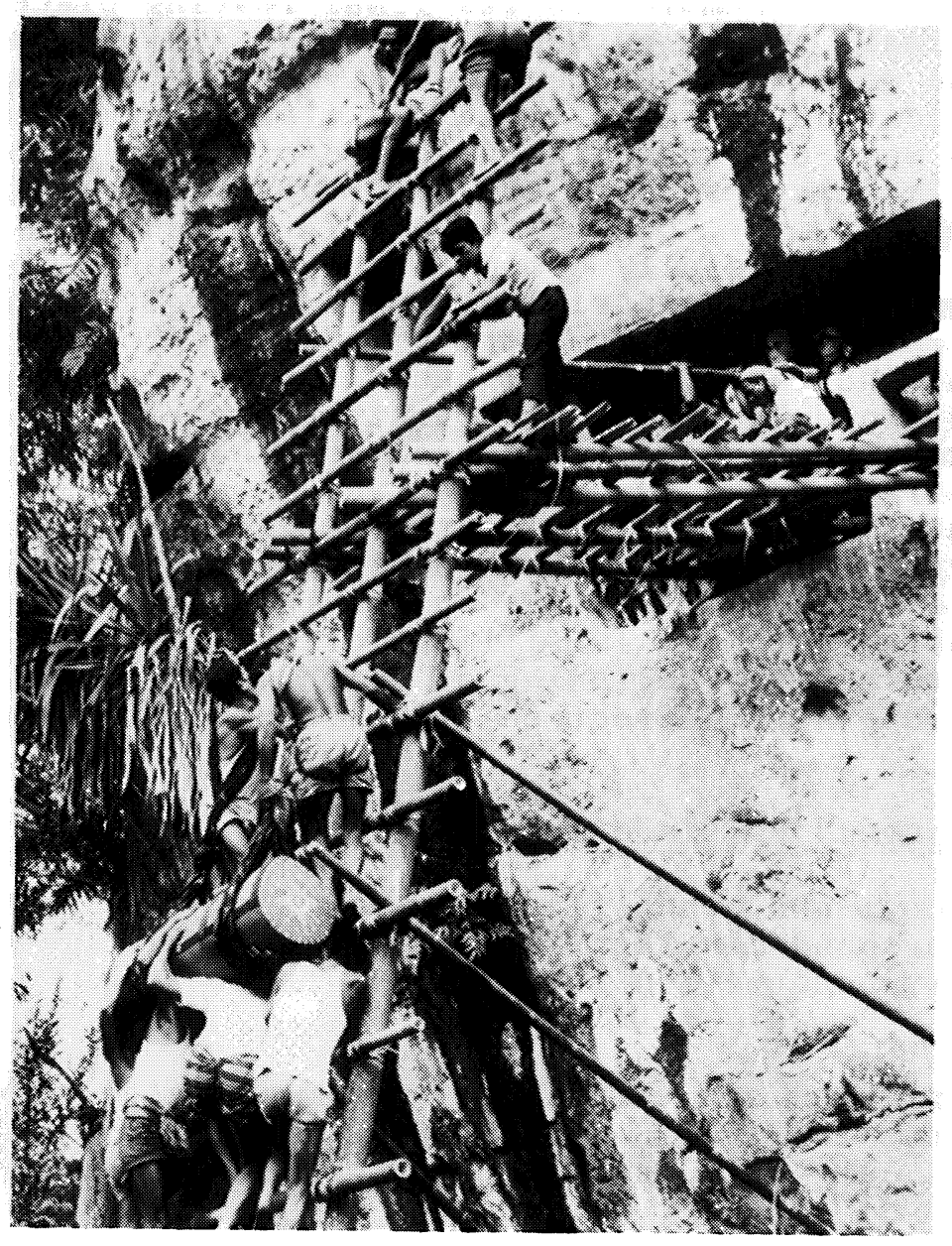

The body of Puang Pantan, wrapped in red and embellished with gold leaf sunburst design, is brought to final burial. (Note tou tau statues in upper right.) 
Kepala was impelled to play not only cooking pot politics in strict traditional terms, but also to maintain an awareness of the direct effect of his actions as traditional leader and festival organizer on the outcome of a contemporary electoral contest. So indeed the Pantan funeral, from the butchering of the first buffalo to deposition of the body in a high cave vault, proceeded in a most traditional and incidentally most munificent manner. The carver of the tau tau statue, the priests of death who had wrapped the body, the village leaders who had contributed mightily to the organization of 1 abor for the construction of the ceremonial ground seemed in general agreement that the funeral had proceeded as it should, that their efforts were compensated in keeping with ancestral tradition. The largesse of Puang Kepala was particularly great in the case of Buissun and Burake village complexes, the regions in which he himself resided at Tandung. Each of these villages had been especially responsive both to their traditional obligations to a dead Puang, and also to the special and unanticipated needs of Puang Kepala in staging the event. When a construction team arrived at Pantan shorthanded, if bamboo or arenga palm twine were exhausted, should a pig be required immediately, the people of Buissun and Burake could be counted upon to fill the breach. In Toraja funerary practice the largest number of buffalo are normally dispatched on the day of burial when most of the guests have already evacuated the ceremonial site and only close family members and local village people remain. On a chill morning at Pantan a score or more buffalo were tethered on the irregularly sloping terraces upon which the ceremony had been held. The body atop the lakkean, wrapped in red cloth and adorned with gold leaf was soon to be removed to its final resting place. Butchers moved among the animals selecting those for immediate slaughter. The distribution of the meat would proceed quickly before the warm sun attracted hordes of flies to the scene. The mud-flecked grass and ground-down stubble soon were colored with the blood of many large bovines. Other beasts were led away, some reserved for government tax on the animals killed at the ceremony, others to be held permanently in reserve by relatives who had carefully computed their personal and social requirements. Buissun and Burake villages were each given one tedong, which were forthwith killed and the meat divided between village principals (choice cuts) and rural folk in general. This particular distribution was not determined by ritual precedent, but by the wishes of Puang Kepala who thus endeavored both to express his gratitude to the villages of his region and to bind them yet more closely to him in the days and months to come. The great prestige which accrued to Puang Kepala as organizer of the Pantan death ceremony would long be savored by the Makale noble family. The successful conclusion of the great ritual suggested both the fulfillment of the ritual obligations of the local nobility and the beginning of a long process which would culminate in the renewal of direct political control by the Puangs of Makale.

\section{Political Change: Parkindo Control}

Educational and evangelical endeavors of the Calvinist Gereformeerde Zendingsbond ${ }^{9}$ in Tana Toraja followed hard upon the initial Dutch military penetration in 1905-6. The ceaseless efforts of Chris-

9. An excellent sketch of church history and educational endeavor in Tana Toraja is provided in J. A. Sarira, Sketsa Pendidikan Kristen Geredja Toradja 1913-67 (Sketch of Toraja Church Christian Education 1913-67) (n.p.: Pertjetakan Geredja Toradja, 1967). 
tian institutions and organizations have profoundly influenced the complexion of local society in political as well as in religious spheres of 1 ife. Although missionary efforts in Tana Toraja were at first thwarted when the pioneer evangelist and scholar of the Toraja language, A. A. van der Loosdrecht, was lanced to death in July 1917, the dogged determination of his successors yielded gradual progress. By the fourth decade of Dutch rule almost half the populace had accepted Christianity.

By far the largest Christian organization is the Gereja Toraja (Toraja Church) whose membership is intertwined closely with that of the Indonesian Christian Party, Parkindo. Indeed, several ministers of the church have held high posts in the Toraja branch of Parkindo, causing them to be derisively labeled "Pendeta politik" (political preacher) by their"opponents in local society. One interesting aspect of the Parkindo/Gereja Toraja axis is the fact that most of the people commanding leadership positions within its fold have been descendants of the To makaka group. Suffice it to say that the interlocked leadership of Protestant church and Christian party have reflected, in their determination to effect universal change in Tana Toraja through the manipulation of powerful church-affiliated institutions, much of the ancient antagonism of the To makaka towards the local nobility. Although many members of the Puang caste have converted to Christianity, generally speaking the church and its affiliate organizations have offered the To makaka group easiest access to the extra-traditional "modern" stream of life in Tana Toraja.

At the present time the church enjoys a virtual monopoly on higher education throughout the regency. Church schools far outnumber government educational institutions in villages.10 The two bookstores in Tana Toraja are exclusively stocked with religious literature monopolizing all printed matter available for sale to school-age youngsters. Government elementary, middle and high schools manifest facilities markedly inferior to those of parochial institutions. A church-run Teachers' College in Makale and a theological seminary in Rantepao are complemented by a well-equipped technical school, all of which benefit greatly from direct overseas financial support. The contrast between national and mission schools is nowhere greater than in the realm of technical education. The government Sekolah Teknik Menengah (Middle Technical School, STM) at Rantelemo is totally bereft of the simplest piece of machinery; students are thus restricted to "theoretical" studies or the practical exercise of constructing school benches and chairs for sister institutions. In contrast, the church-sponsored technical school is outfitted with an electric generator, a large power saw, internal combustion engines, and most significantly, a technology specialist dispatched from Holland by the missionary society to direct the entire operation. The services of the latter individual are not available to students at government schools. During the Pantan ritual students from the local technical school volunteered their time to aid in the construction of the lantang. After a few hours of work they

10. Generally speaking there are about twice as many parochial as government schools in Tana Toraja. Of a total of 279 elementary schools (sekolah dasar) 80 are government run, 151 are under the aegis of the Yayasan Perguruan Kristen Toraja (Toraja Christian Educational Foundation, an organ of the Gereja Toraja), and 40 are administered by the Catholic Yayasan Paulus. Two madrasah (Islamic schools) are maintained in the regency. Figures are from the Regency Office, Education Division, Makale. 
were asked to withdraw as they were found to be totally inept at working with bamboo lashes and tongue-and-groove construction. Simple villagers replaced them as the danger of an il1-constructed 1antang 1ater collapsing under the weight of scores of guests was too great to allow for the practical inexperience of technical school students. Everywhere in Tana Toraja the wealth and influence of the Gereja Toraja is apparent. The best kept structures in Makale town are the parochial high and middle schools. Unlike the government high schools, these centrally located edifices are walled with plaster, floored with concrete and illuminated through glass windows. The government school is approached only by foot (the automobile bridge leading to it has been impassable for years) and is walled with whitewhashed plaited bamboo.

The social life of the urban elite is dominated by a constant round of neighborhood prayer meetings, Sunday services, weddings, and religious holidays. High interest in funerals is of course maintained, but major events of this nature are almost always carried out in the natal village of the deceased. Sundays witness the filling of the churches, especially with young people garbed in their best trousers and dresses, clutching newly purchased Bibles and hymn books sold in the local bookshops. Enthusiasm for the neighborhood and youth associations, schools, athletic teams, women's organizations and choral groups of the Gereja Toraja runs high among that portion of the populace which has embraced the dominant Protestant faith. But more than religious devotion is involved here. For youngsters the church offers the principal hope of participation in the world beyond the confines of traditional village agricultural and ritual cycles. Leaders in the church youth groups often receive opportunities to attend province-wide conclaves, selected individuals participate in national meetings of Christian youth organizations affiliated with the Dewan Gereja Indonesia (Indonesian Council of Churches). Graduates of the local parochial school system may choose to remain in Tana Toraja to receive a college degree from the church-operated teachers' college. If economically possible they may travel to Java for advanced education, most often following a well-worn path to the Christian University of Indonesia at Salatiga. Many will hope to return to Tana Toraja, some to remain within the theological fold working as ministers in town and village, others finding a niche in the widespread educational system which everywhere seeks as its primary goal the conversion of additional souls to the Christian fold. The opportunities made available by the Gereja Toraja to the youth of the regency are tangibly great; 1ittle wonder that increasing numbers of young people quickly engross themselves in the parochial modernism of the Toraja Calvinist world view.

Graduates of Gereja Toraja educational institutions have found positions in government service, in the armed forces, and in private business in great disproportion to the Toraja population as a whole. Toraja civil servants are dispersed throughout the archipelago with small community associations in Yogyakarta and Jakarta growing up principal1y about the churches in those towns. Nevertheless, many students find assignment outside of their home territory unappealing. Numbers of graduates have declined government assignments to small Bugis towns where, as the only Toraja Christian in an Islamic community their position would be socially untenable. For this reason, and also because of the strong positive attraction to village and natal household, there are today a great number of former primary, middle, and high school students who have become resigned to a rural existence in Tana Toraja. Many of these individuals serve as teachers in church schools in the villages, practicing subsistence farming to augment their meager incomes (Rp. 1350 per month). Others are without salaried employment whatsoever. Parents 
often complain that the great expense of sending their children to school has been rewarded with lazy, shiftless children too proud to strip to the waist to transplant rice in muddy ricefields, too arrogant to draw water at dawn from common village wells. Participation in church-related activities remains the fragile link with the cherished ideals of modernism. The number of educated, unintegrated peasant youths in Tana Toraja seems bound to increase dramatically in the years to come if openings in the civil service remain few and the present freeze on school construction and teacher hiring continues. The Gereja Toraja, increasingly pressed for funds by shrinking contributions from abroad, may be able to maintain its extensive educational network for years to come, but occupational opportunities within the church structure are bound to remain restricted for the foreseeable future.

The church has offered a new faith, an alternative life-style, and myriad opportunities for full participation in the modern Indonesian world through its highly developed religious and community institutions. The ever-present Dutch missionaries have exercised a strong doctrinal influence on their students in the local seminaries, preaching a fundamentalist faith perhaps foreign to most Hollanders these days. Before each meal long prayers to the Lord are invoked; Sunday church services usually last two or three hours, testing the patience of local villagers and the endurance of indigenous preachers. Except for two churches in the towns of Makale and Rantepao, all services of the Toraja church are conducted in the regional 1 anguage. Church-goers are drawn from all strata in the population and from diverse age groups as well. In each village the church leadership is usually in the hands of the local schoolmaster. Funds for the construction of new churches are normally collected each Sunday; common work efforts have seen the raising of many substantial houses of worship throughout Tana Toraja.

Christian religious ceremonies often closely parallel adat traditions. At the conclusion of the harvest period special foods normally prepared at an Aluk To Dolo harvest ritual are brought to the church and a common prayer service of thanksgiving is held on the mutually agreed-upon Sunday. Should a prominent church member erect a new house, a Christian religious ceremony will be held to which the relatives of the new homeowner will be invited. Often non-Christian relatives of Christian festival-givers contribute to the ceremony, remaining on the peripheries during the religious service but participating in the shared communal meal which inevitably follows. It would appear that the substance of ritual practice has altered little; only the form of prayer and worship have changed.

Nevertheless, the commonly noted "mixing up" (dipasirau rau) of faiths in village communities has led to significant cleavages among families and neighbors over the years. One question which agitated the Christian community for several decades was the traditional distribution of meat at the close of a death festival. The issue hinged around the bukuleso, the rear leg joints of pigs or water buffaloes distributed as tokens of respect to village notables at the close of major funerals. The church refused to sanction this practice, stating that an aluk religious connotation was attached to the joint; church members were forbidden participation in such distributions. In practice, substitute cuts of meat were usually proffered to honored village leaders, yet many elders and nobles refused to accept surrogate offerings, making no compromise with alien church practice. Christian farmers have also refused to contribute to what formerly were village-wide celebrations at the end of the agricultural year, declined to participate in 
the common thanksgiving ceremony for the avoidance of smallpox and measles, and abstained from actively joining in triennial possession rituals. Although conditions differ from region to region, in general an adjustment in community relations has been occasioned by the religious factionalization of local communities. Nevertheless, the great, inexorably recurring death ceremonies continue to function to unify the diverse religious groupings. One receives the distinct impression that although pronounced religious differences do sometimes result in community tension, shared kin, territorial and customary law traditions in most cases suffice to overcome the problems generated by a diversity of faiths. More severe are the conflicts within families stimulated by the school experience of children whose parents are non-Christians. Current regulations oblige religious instruction in government as well as in parochial schools. But the pressure for conversion is much more intense in schools financed by the Gereja Toraja itself. Traditionalist parents often complain about the ever-rising costs of schooling and its deleterious effects upon family unity. Indeed, one oldster confessed to me that he and his wife had embraced Christianity only after their Protestant son employed in Kalimantan declared by mail that he would never return to the courtyard of his home until his parents had forsaken their "animist" ways. The pressure for conversion remains great, yet interestingly a plateau in Christian affiliation seems to have been stabilized over the past twenty years at about 40-45 percent of the total populace. Often the crucial factor in religious conversion is the attitude of village leaders or nobles, the most respected members of the community. If such key individuals can be drawn into the Christian fold then the bulk of the populace usually follows suit. Nevertheless the dispersed nature of residence locations and the often stubborn determination of recalcitrant individuals makes for a situation where no village in the Makale valley can claim 100 percent adherence to the new faith.

The deep penetration of Christian organizational activities and institutional forms into Toraja life bears political as well as social implications for life in Kabupaten Tana Toraja. On the village level these political implications may wax and wane about issues such as the disposal of the bukuleso joints or the dispatch of buffalo horns at the close of a major ceremony to nearby Puang (the traditional way) or to the local minister (the Christian way). But in more universal political terms the implications of church organization are plainly evident. Since 1950 and the assumption of power in the region by KNI, the government of Tana Toraja has been effectively in the hands of the Protestant party.11 With the formal establishment of Tana Toraja Regency in

11. The formation of a Komite Nasional Indonesia (KNI) in Tana Toraja occurred much later than the similar events in Java described by Benedict Anderson. Nevertheless, the rise of such ad hoc governing bodies across the archipelago manifested universal aspirations towards self-government and the rejection of the privileged nobles through whom the Dutch governed indirectly up until their departure. In Tana Toraja the formation of the KNI led to immediate conflict with the nobility, at least one of whom was imprisoned in 1950 in Makale by the schoolteacher Rongre who came to head the KNI. The nature of these national committees is best expressed by Anderson: "Spontaneous, self-appointed, and local in character, the committees marked the disintegration of former hierarchies and the urgency of liberation. At heart, the formation of each committee was a local proclamation of independence, similar to rather than an extension of, the Djakarta proclamation of August 17th." (Benedict Anderson, Java in a Time of Revolution [Ithaca: Cornel1 University Press, 1972], p. 117.) 
1957 , fifteen out of the twenty Regional People's Representative Council (DPRD) 12 seats in Makale were allocated to Parkindo. ${ }^{13}$ Up until July 1971 the overwhelming majority of representatives seated in the DPRD here by virtue of electoral percentage remained delegates of the Protestant party. Similarly, representatives of Tana Toraja to the DPR-I in the province capital, Makassar, were invariably drawn from Parkindo leadership ranks as were the several Toraja delegates to the national parliament over the years. Working through its highly organized, well-staffed and financed party structure, the Parkindo organization seemed to have assured itself a continual monopoly on political control of the regency.

Undermining the apparent unanimity of Tana Toraja behind the Protestant party, however, were the festering conflicts of caste and tensions of ${ }^{i}$ religious heterogeneity effectively masked from external view by the evident Parkindo domination of the region. The nobility, which under forty years of colonial rule had been the beneficiary of Dutch tutelage and appointment to district headmanships, was divested of a1most all of its legitimate political functions by the events of 1949-50. The transfer of sovereignty to independent Indonesia signaled, in Tana Toraja, the final demise of the Dutch system of indirect rule through appointive nobles. Puang district heads and notable village leaders were soon displaced by middle caste politicos unified behind the Parkindo banner. Nevertheless, the taste for political power and the practice of political intrigue remained close to the hearts of the dispossessed. Gravitating towards secular nationalist parties (PNI, Partindo) during the Sukarno era, these forces perceived an opening to power in the cataclysmic events of September 1965. Throughout Indonesia the September 30 th coup failure stimulated the assumption of an ever greater political role by the armed forces at the expense of the traditional parties. In two and a half years of firm government the New Order made it clear that political parties would now conform to government policy imperatives or face increasing checks on their freedom of organization and action. The secular nationalist forces in Tana Toraja in 1968 had abandoned the storm-tossed PNI ship and were aggregating about the flag of a new vessel of non-religious political activity, IPKI (Ikatan Pendukung Kemerdekaan Indonesia--League of Upholders of Indonesian Independence). 14 The latter party was closely affiliated

12. Dewan Perwakilan Rakyat or People's Representative Council, is parliament. The national parliament in Jakarta is referred to simply by the initials DPR, the provincial assembly by DPR-I and the local (daerah) body by the initials DPRD.

13. The 1957 allocation of seats in the new regency legislature saw Parkindo holding fifteen of a total of twenty positions in the DPRD with the PNI, PKI, Catholic, and Masjumi parties being assigned one seat each. Representation was accorded on the basis of 1955 election returns in the Makale and Rantepao administrative areas then under Kabupaten Luwu, which gave 78,599 votes to Parkindo and only 6,633 ballots to Masjumi, the second most successful party.

14. Danie1 S. Lev described in The Transition to Guided Democracy (Ithaca: Cornel1 Modern Indonesia Project Monograph Series, 1966), p. 14, the close links between IPKI and the army in tracing the origin of this party to efforts in 1954-55 by a group of former army officers, including General Nasution before his return to the position of Chief of Staff. It was more of an army pressure group than a party. Once back in command of the army, Nasution gradually pulled away fron IPKI, though he maintained some influence over it. But IPKI continued to represent an army point of view and increased in significance during the next few years as the army itself became politically more active. 
with the army. Although IPKI's existence long preceded the coup attempt of 1965, its rapid proliferation in Sulawesi was linked with government attempts to counter the continued influence and organizational momentum of the established parties.

An important local issue catalyzed the political forces of Tana Toraja in February 1967. At that time the Parkindo-dominated Toraja legislature enacted perhaps the most controversial regulation in the history of modern government in the region. The adat market system, following a six-day cycle, was to be adjusted to the Gregorian calendar in order to ensure that principal market days would no longer fall on Sundays. Although normally enthusiastic about church attendance, Christian villagers and townsmen had through the years evidenced a marked predilection for the social and commercial attractions of the bustling marketplace over the three-hour solemnity of the Sunday worship service. Church leaders, long perplexed by this dilemma, succeeded in 1967 in encouraging Parkindo to legislate the first such change in the traditional market system in memory. Riots at several locations were narrowly averted by the police; villagers whose computation of agricultural activities and ritual events closely follows the cycle of markets accommodated themselves to the new arrangement with great reluctance and considerable resentment. In retrospect this initiative on the part of Parkindo signaled the beginning of the end of its power monopoly in Tana Toraja Regency. When Desa Gaya Baru elections were held in villages throughout the regency in 1968-69, the most telling argument for a change in political leadership was the issue of traditional market vs. the Parkindo blue law approach. Villagers affiliated with the Aluk To Dolo faith were most upset by the change. It was this mass of traditionalist rural folk who were actively sought out by the local organizers of IPKI, leaders whose positions of rank and influence in the traditional social structure made them the natural heirs to the prominent positions once exercised by their fathers during the colonial era. The village elections were formally carried out in the absence of declared party affiliation; candidates were to be nominated and then verified as individuals rather than as representatives of political parties. Nevertheless, voters were fully cognizant of the political affiliations as well as the social origins of the candidates fielded in the Desa Gaya Baru electoral contests.

Electoral Challenge

Makale town proper and the surrounding village communities were aggregated into one Desa Gaya Baru called Lembang Bombongan (pop. $\pm 9000) .15$ The Lembang Bombongan area comprised the urban core and the Tondon village to the southeast, Kamali/Pentalluan village to the northwest, and the Burake/Buissun complex to the northeast of the town proper. The latter region was of course the home locale of Puang Kepala, the region where the great death ceremony of November 1968 transpired culminating in the burial procession which bore the late grandfather of Puang Kepala from the Pantan ceremonial site, through urban center and marketplace to the family vault chiseled into a limestone

15. The name "Lembang Bombongan" was chosen in recollection of the precolonial Makale marketplace situated at a locale termed Bombongan. The word lembang means either boat or geographical region and is an area specific to Tana Toraja. Similarly, Bugis villages to the south adopted the term "wanua" to be used as a local language variant of "desa" with reference to the newly formed Desa Gaya Baru. 
cliff at Tondon. The candidacy of Puang Kepala, emergent at the death ceremony itself, took on a more active and formal nature with his nomination a few weeks after the buria1 of the old Puang. The election was formally scheduled to be held in January 1969. Three other hopefuls were nominated. Each of these three was either an active-duty or retired military man; only Puang Kepala was a civilian. His opponents in turn represented the Muslim community in Makale town, the Parkindo faction, and a regional/student group with territorial loyalties to the western Toraja districts. Amid much tension the day of the election approached. Identity cards were issued to citizens and checked by local police during the week prior to election day. All activity at the Makale market was halted because voting booths and identity card check-stands were located in the central selling area. Each candidate was seated on a platform. Alongside each hopeful was a symbol (a gas lantern, two cultigens and a dragon's leaf plant) and a number. Inside the voting booth the number, symbol, and photograph of each candidate were affixed alongside a bamboo tube into which voting chits were to be deposited. The election proceeded until six in the evening without serious incident. At the close of the electoral process the four tubes were brought out into public view, split open with a large knife and the voting chits were carefully counted by regency government officials before the eyes of several hundred assembled spectators (many of whom had staked high wagers on the outcome). The winner was Puang Kepala.

The victory signified more than the personal triumph of a minor noble within his natal territory, more than an exchange of personnel in the established political order. The Makale region in which the election had occurred is the political heart of Tana Toraja, and so the selection of the new kepala lembang indicated an important shift in political relations in the region. For the first time since the colonial era a Puang had won an open election in the Makale area. (The last noble to hold the appointive position of Makale district head, a close relative of Puang Kepala, met his death at the hands of unknown assassins a decade previous to this election.) The factors contributing to this unprecedented popular victory were Puang Kepala's years of service in the tax division of the Regency office, his ability to elicit the loyalty of traditionalist villagers to his person and rank, his largesse as evidenced during the Pantan death ceremony, and his association in IPKI with military officers and influential politicians closely tied to the province army command. The victory by plurality evidenced Puang Kepala's success in manipulating traditional loyalties to contemporary political ends and clearly indicated the imminent eclipse of parochial party politicians long entrenched in the Toraja capital by secular nationalist forces in close alliance with the military. The glum faces on the supporters of the Parkindo candidate after the election were reflected in the comment of one dejected supporter of the opposition as she walked home to her village after the ballots had been counted. "There is no beating the noble house," she commented. The election results here were for the most part indicative of the outcome of contests in the fifty-two other lembang completed during the following months. Although Parkindo candidates did take a number of these village elections, especially where their candidacies were effectively uncontested, the great majority of New Style Villages fell to the leadership of IPKI-backed individuals. The events of 1968-69 clearly presaged the outcome of the national elections scheduled for Ju1y 1971 .

The same political forces which had coalesced behind the candidates in the lembang elections now mobilized their forces for the national campaign. The stakes in this election were high: control 
over the local DPRD in Makale, representation of the regency in the Makassar legislature and the delegation of a regency representative to the national DPR in Jakarta as well. The role played by the central government and civil administration was dramatically altered in 1971 . Much added strength now accrued to secularist forces with the compulsory participation of all government civil servants in the new Golkar organization. Of the kepala lembang associated with Parkindo, only one refused to participate in Golkar and he was summarily relieved of his position. The national election campaign transpired without major incident or confrontation. One parochial school student was killed in an automobile accident while en route to a Parkindo rally. A number of Parkindo partisans, including one minister, were held in preventive detention until after the elections and a scheduled Parkindo demonstration of strength (march and rally) was banned in Makale town. Unlike the lembang elections two years earlier, party affiliation was now prominent and paramount during the campaign. The Christmas tree and candle symbol of the Protestant party was widely displayed, as were the banyan tree of Golkar and the symbols of the other eight parties. Each political party fielded a slate of candidates for local legislative office. The results of the election and the proportional allocation of seats to the DPRD were announced in late July 1971. To the surprise of few, Golkar registered an overwhelming victory. For the regency as a whole, all political parties combined polled 16.6 percent of the vote with 83.4 percent going to Golkar. 16 The candidates fielded by Golkar had been carefully chosen, drawn from Protestant, Catholic, Muslim, and Aluk To Dolo religious communities. Indeed, for the first time in Toraja history Parkindo was not only displaced as the controlling power in the legislature, but more Aluk To Dolo adherents than Parkindo representatives were to be seated in the new legislative body.

The thrust of Parkindo political activity in the past had been principally designed to enhance the Christianization of Tana Toraja, to further the construction of church-controlled or subsidized schools, and to mold local society as closely as possible towards the Calvinist model of the ideal society. Adherents of the ancestral Aluk To Dolo religion had been ignored in those times in so far as their intractability with respect to conversion was firmly established. Unrecognized as a religion, the ancestral kepercayaan (beliefs) were denigrated by school authorities. After the 1965 coup, religious instruction became mandatory in all schools. Students from traditionalist families were effectively forced to accept Christian or Muslim religious teachings since satisfactory performance on religious examinations was a prerequisite for advancement and eventual graduation. Only with the issuance of a 1969 edict from the Ministry of Religion was Aluk To Dolo recognized by the national government as a "sect" of Hindu/Dharmal 7 and thus granted official status as a religion. The lembang elections of 1968-69

16. Official election results were publicized on July 21,1971 , by the Regency Office in Makale. Of a total of 142,795 votes cast for delegates to the local Makale DPRD legislature 119,096 were tallied for Golkar, 16,301 for Parkindo and the balance of 7,398 for the other eight political parties on the ballot. Parkindo thus registered twice as many votes as all the other parties combined even though its share of the total vote was only about 11 percent of votes cast. After Parkindo the Partai Katolik polled the next highest number $(3,445)$ followed by the Partai Muslimin Indonesia $(1,317)$.

17. A Balinese-centered Hindu movement which has spread rapidly in recent years, particularly in East and Central Java. 
had clearly proven that members of the old noble caste could command the loyalty of traditionalist villagers in an open contest for locallevel political leadership. The 1971 national elections saw the same forces contesting political power on a regency-wide scale. The banner of Golkar was held highest once again by members of the former privileged groups through whom the Dutch had ruled during the colonial era. So it was that the Puang of Mengkendek would slaughter a water buffalo several days prior to the national election in the context of a Golkar rally at her ancestral home at Minanga. Attending the feast were prominent Golkar leaders including her daughter-in-1aw (subsequent1y elected to the DPRI in Makassar). Parkindo laid heavy emphas is upon the organization of eligible students during the campaign. Indeed, the highest party vote was attained in the town of Rantepao where the Gereja Toraja high school and theological seminary are located (28 percent of the votes to Parpol, 72 percent to Golkar).

Developmental Perspectives: Secular Renascence

In the aftermath of the national election the degree of transformation in the Toraja political order could begin to be assessed. Parkindo hegemony was now to be replaced by Golkar monopoly rule. The importance of this quiet revolution in political dominance can best be ascertained by reference to the unique base upon which Golkar fashioned its victory. Led by members of a local nobility which for a generation had been denied access to effective political power, the governmentbacked secularist forces here depended both upon mass support from traditionalist villagers and large doses of financial aid from the panglima (commander) and national sources outside of Tana Toraja. The mass infusion of Honda motorbikes and accelerated development funds prior to the election was as evident here as elsewhere in the archipelago. Golkar's internal strength in Tana Toraja was drawn from the considerable economic power and sustained social prestige of its local community leaders. The disparate political orientations of Golkar and Parkindo were quite clearly perceived by illiterate villagers whose ability to discriminate self-interest on political issues of market cycle and religious tolerance was manifest in the election results. Perhaps the great prestige of Golkar as the government party would have sufficed to bring it to victory in 1971 even if the issues peculiar to Tana Toraja were not important factors. But the reality of the 1968-69 lembang elections had generated significant political momentum behind the secularist challenge. What changes were to be effected as the result of the shift in political control? The markets would return to their original, adat cycle. Gambling restrictions would be relaxed, and religious tolerance would be assured. Such innovations were to transpire in a general economic climate of positive change. To the observer returning to Makale after a two-year absence, the proliferation of consumer goods, the opening of many new stores, the initiation of tourist development projects clearly showed the impact of national economic strategy. The stabilization of the price of rice, work on cement gutters in Makale town, even the common availability of plastic wrapping material in central markets where formerly only banana leaves were used manifested the positive effects of policies emanating from Jakarta in this particularly remote corner of the archipelago.

Government energies in 1971 had been largely devoted to election planning and campaigning to the end of ultimately replacing an increasingly intractable Parkindo faction with delegates responsive to the wishes of the government. This is not to say that particular develop- 
ment schemes were not already underway. Recently the road between the two major Toraja urban sectors had been paved, linking the Rantepao market complex and the Makale administrative center with blacktop for the first time. "Development through tourism" was the way the bupati (regent) explained his economic strategy for the immediate future. To this end access roads were improved leading to Londa and Rantelemo, the traditional burial sites frequented by the ever-increasing stream of tourists making their way to Tana Toraja from Makassar. At a cost of eleven million rupiah Wisma Hasanuddin had been constructed in 1969 at the roadside at Pantan. Financed by the Panglima of Corps XIV Hasanuddin, this impressive structure was to serve as hostel for high officers and officials when visiting the region and as a tourist facility at all other times. A striking bathroom of whitewashed plaster walls and corrugated iron roof, its wooden doors embellished with traditional incised designs was already completed at the Rantelemo burial site. This tourist convenience was prominently situated between the road's edge and the burial site (dominating the once pristine view of high cave vaults and aging wooden tau tau statues). Throughout the regency each kepala lembang was responsible for the planning and execution of his own rural development project--to be undertaken with the aid of unpaid local labor. A cursory perusal of surrounding villages revealed that most such efforts were dedicated to the construction of additional motor roads into the lembang hinterlands. A number of reinforced concrete bridges were built on a contract basis by private entrepreneurs at the behest of the regency administration.

The new government position on cockfighting indicated a complete reversal in outlook. In a 1968 Christmas address attended by this researcher a Parkindo representative equated cockfighting with communism, both of which were to be finally crushed by the relentless vigilance of God-fearing men. Under the old order in the regency cockfighting was anathema and thus banned from both urban center and village courtyard. This edict, along with the imposition of the fixed market days, accounted for considerable tension in the countryside. According to local adat, cockfights traditionally were to be staged at the conclusion of a large death ceremony as well as in conjunction with other religious rituals. Violators of the ban on cockfighting were subject to imprisonment, fines, and the confiscation of their birds. The liberalization of the policy with respect to adat events began after the lembang elections concluded in 1969. In 1971, after the national elections, it was announced that month-iong government-sponsored cockfights would be held--first in Rantepao and upon termination there another month of the sport would follow in Makale. These events were officially sanctioned in order to raise money for development projects. Local gossip supported the theory that the legalization of cockfighting was a display of thanks by the government to the public for handing such a sound victory to Golkar during the elections. In Makale the site of the cockfighting was to be the central marketplace now used once every six days for the adat market and otherwise peopled by scattered vendors of fruits and vegetables on interim days. The marketplace was converted into a site for a pasar malam (carnival) replete with many other games of chance and a somewhat incongruous Ferris wheel which a concessionaire had transported in sections up from Makassar. Entrance into the carnival grounds cost 50 rupiah, no mean sum for villagers many of whom sold reserves of padi in order both to meet the entrance fee and to arm themselves with sufficient cash for wagers. Each morning long streams of men could be observed pouring into town from all directions, cradling preened fighting cocks in their arms. Buses and trucks from Rantepao also brought participants from more 
distant locales, each vehicle invariably topped with the securely tied bamboo cages of fighting birds. When regular market days occurred, the village folk and professional vendors were required to set up outside the bounds of the market qua carnival grounds. Fund-raising schemes thus took precedence over normal market activities. In fact the scene on market days was one of great confusion. The traditionally structured pasar was thrown into disarray, no one knew where to meet relatives and friends, where to purchase sirih or rice, or where to aggregate with vendors of like goods. Scheduled for four weeks, the Makale pasar malam dragged on for six weeks and in the end even the pent-up local passion for cockfighting seemed to have been thoroughly exhausted. As for the funds collected during the event by the government, original plans to utilize them to build a large fountain ("for the benefit of tourists") were at the last minute abandoned. Two months after the close of the carnival no new development projects had been announced and the ultimate disposal of the development funds remained a mystery.

Development P1ans and Prospects

August 1971 marked both the twenty-seventh anniversay of Indonesian independence (August 17, 1945) and the fourteenth anniversary of the establishment of Tana Toraja (August 31, 1957) as a separate regency. The August 31 ceremony was commemorated with much speech making at the Regency Office in the center of Makale town. In his prepared address Kepala Daerah Tampubulon presented a synopsis of his development plans for the Toraja region. The regent conceptualized the following steps to be undertaken immediately: "1. Raising the production of padi through the newly instituted Bimas program. 2. Increasing saleable livestock, especially with respect to newly introduced Yorkshire pigs and Leghorn chickens (each household was to endeavor to market two purebred pigs annually and at least five eggs weekly). 3. Encouraging the planting of cloves and coffee as long-term investments. 4. Stimulating community interest in local culture to facilitate the development of Tana Toraja as a prime tourist area. 5. Maintaining the national highway, provincial roads, and village pathways. 6. Hastening completion of the planned airfield at Rantetajo." In conjunction with the fourteenth anniversary of the establishment of Tana Toraja, the Regency Office prepared for publication a Brief History of Tana Toraja Regency. Half of this forty-one page document was devoted to a delimitation of past, present, and future development projects undertaken in the region. Perhaps the most interesting comments offered in the "Inventory of Plans of the Regent of Tana Toraja" are those directed towards the schools. The (anonymous) author's comment under the category "school situation" that the government desires to "effect stabilization in the life of schools and universities" by means of: "a. Cleansing teachers, school officials and students of interests pertaining to political parties or specific groups; b. Effecting decisions of government which forbid the utilization of schools or universities as arenas for the competition of political party influence; c. Guaranteeing the rule of law in teacher and school official's circles; d. Directing student and pupil organization towards the goal of national unity." "The above mentioned situation," the report on education concluded, "requires special discipline for and by the Foundation Schools in the hinterlands." 18

18. Sedjarah Ringkas kabupaten Tana Toradja (Brief History of Tana Toraja) (Makale: Kantor Kabupaten, 1971), pp. 30-31. 
The Brief History of Tana Toraja Regency outlines a rather exhaustive compilation of development possibilities ranging from the exploitation of gold, copper and tin mineral resources to the improvement of sanitary and health conditions. A long list of irrigation, bridge, and road-building schemes currently under way is provided. The potential of the tourist industry is stressed; plans for the construction of three hotels and a landing field for light aircraft are aired. Each year since 1968 tourist interest has in fact increased. Since 1970 organized European tours have visited Tana Toraja with increasing frequency; many groups fly into Makassar from Den Pasar. A large pintu gerbang (welcome gate) of reinforced concrete has been constructed by the army at the southern border of the regency. Great sums were expended in the raising of the large Wisma Hasanuddin hostel at the roadside at Pantan just north of Makale town. The solution to the most pressing problem of the regency, inadequate food production, was seen in the planned increase in padi production through the Bimas program and the stimulation of pioneer settlement on unoccupied lands. The cultivation of 17,697 hectares of padi 1 ands by a population of 306,000 has in recent years yielded rice sufficient on the average for only seven months of the year. In 1971 only 50 percent of target rice lands were actually reached by agriculture officials entrusted with the execution of the Bimas program. The encouragement of migration to the sparsely populated Toraja hinterland and the fertile coastal regions north of $\mathrm{Pal}$ po seems to offer some promise. The north Palopo coastal plains have for thirty years been the target regions of considerable Javanese migration. Since the end of the Darul Islam revolt in 1965 , increasing numbers of Toraja villagers have moved to regions such as Batistanduk and Lamasi where mixed Toraja-Javanese populations have successfully opened vast new rice lands. Government efforts to encourage further Toraja migration are underway. Judging from personal impressions only, this type of resettlement seems particularly promising. In attempting to evaluate development plans in Tana Toraja one is most severely hampered by a lack of public accounting of funds spent. A1though the dropping of $\mathrm{Rp} .75$ per head in local villages had been announced, local residents remained unaware of the disposal of such funds. Attempts to elicit a detailed scheme of expenditures from the Regency Office proved repeatedly unsuccessful. The many projects delineated in the documents cited above have limited heuristic value in the absence of hard financial data detailing their relative priority in the eyes of regional administrators. Nevertheless, a few comments with respect to the apparent thrust of current development programs in the regency may be relevant. The monthly export of 600 head of purebred pigs has been a remarkable success story in a region which ten years ago supported on 1y bristle-haired swaybacked swine of traditional breed. In the midand early sixties Muslim villagers in the Bugis and Makassar regions to the south would stone any truck found carrying pigs to Makassar. Conditions have fortunately changed. Most of the swine production in Tana Toraja is carried out by wealthy local or Chinese entrepreneurs. These Yorkshire pigs must be innoculated against disease and fed purchased padi husks trucked up from the rice-milling plants on the plains. Considerable initial capital is required for large-scale commercial pig raising. Nevertheless these babi inggeris (English pigs, i.e., Yorkshires) strains are becoming increasingly common in the pens of ordinary villagers. Indeed, white pigs are beginning to appear at traditional death festivals.

The emphasis at the lembang or village level on new roadways has already been mentioned. In fact the national road just south of Makale to the regency border with Enrekang is in such deplorable condition 
that the concentration of all effort on the maintenance of that crucial 30 kilometers would probably justify the abandonment of most of the individual lembang projects. Similarly, communication links with the western Toraja districts are hampered by poor bridge maintenance. Trucks in 1971 dared not negotiate the Moulu river bridge some 20 kilometers west of Makale. Communications past that river were in about the same condition as in the $1950 \mathrm{~s}$ when Muslim rebels burned the bridges, effectively isolating western districts from the administrative capital of Makale. The allure of tourism, with particular reference to local officialdom, seems to be particularly great. One wonders, however, just how a two- or three-day sojourn of foreigners in the region will benefit the Toraja farmer. Although huge sums may be spent on transport to Indonesia, and large outlays expended for the airfare to Makassar and car rental to Tana Toraja, the expenditure of funds by tourists within the region seems to date to have been minimal. Until now the gracious provision of foreign visitors with food and drink at major death ceremonies has been most generous. In one instance, however, an attempt was made to sell admission tickets to a large funeral, precipitating a bitter family quarrel and the ultimate cancellation of the enterprise. Surveys of Yugoslav and Japanese experts have confirmed that important copper and other mineral deposits do exist in Tana Toraja. However, no one has been willing to invest the capital to exploit these resources. The principal roadblock to development here is the extreme difficulty in communications. Regency roads are generally in very poor condition ("class V" according to local categorization). The vast majority of Toraja villages and all of the identified mineral deposits are far from even regency-maintained roadways-making overland transport extremely difficult. Recent work by a United Nations survey team on the provincial road leading up to Tana Toraja from Makassar and proceeding on to Palopo has progressed with much rapidity. Soon an automobile trip from Makassar may require six rather than the present ten to twelve hours.

In a sense Tana Toraja has always been a closed region, isolated and remote during the colonial era, inaccessible during the war and then cut off during the revolution. With the transfer of sovereignty Southern Sulawesi experienced not peace, but an increase in terrorism at the hands of Darul Islam insurrectionaries some of whom (under the leadership of Sanusi Daris) remain at large to this day. Since the death of Kahar Muzakkar in early 1965, however, peace has returned to the province and the rehabilitation of intentionally destroyed bridges and roadways has in the last three years begun in earnest. The tumultuous political events of the past decades have in sum tended to insulate Tana Toraja from the outside and particularly from the province of which it is a constituent part. The religious affiliations, ethnic identity, linguistic ties and cultural traditions of the populace of Tana Toraja are markedly distinct from the Muslim civilizations to the south. In the recent past these cultural and political differences have led to serious misunderstandings and considerable tension between the people of Tana Toraja and their Bugis and Makassarese neighbors. Recent political developments will most probably ameliorate the physical isolation and political parochialization characteristic of the past. The gradual erosion of the isolation of the region has not been accompanied by a loss of cultural integrity. Current trends indicate a heightened awareness of the rich Toraja cultural heritage. Urban dance troupes have been formed to train school girls in traditional dances. National holidays are celebrated with traditional music and dance performances along with interpretations of modern Indonesian theatrical and instrumental themes. The first national film production ever to be 
filmed in Sulawesi, Latando Di Toradja, premiered in Makassar in July 1971. The movie portrayed an ancient folk tale in which a Bugis prince searches the highlands for a beautiful Toraja maiden. Incorporating cuts of contemporary death ceremonies into the film story the producer made an interesting attempt at incorporating contemporary cultural practices within his presentation of ancient legend. The image of Tana Toraja was further brightened during the March 1971 visit of President Suharto to Makassar. The regency delegation from Tana Toraja, dressed in adat clothing, was invited to a special audience with the head of state. The President was greeted with an invocation from a Tominaa (aluk religious officiant), entertained with Toraja dances, and presented with two black and white water buffalo which are currently pastured at Bogor.

Perhaps the most disturbing aspect of government attention to tourism is the neglect of other aspects of development. Large plateau regions of Tana Toraja enjoy essentially temperate climates where papayas will not bear fruit and coconut palms do not take root. Here the introduction of new crops such as apples (sold in Makassar at Rp. 65 apiece), plums, grapes, and new types of vegetables would seem to be clearly warranted. Sawah 1 and in Tana Toraja is limited and production can only be expanded by the introduction of new strains, and/or double cropping assuming the success of planned irrigation projects. Although the availability of hillside garden lands is great, their utilization appears to be minimal. At present only the first beginnings of truck farming, as opposed to subsistence agriculture, are noticeable in the environs of Makale. Yet the population is so dense close to town that commercial production in the sparsely populated hinterland might be' recommended. A tour of Makassar city markets indicated poor quality fruits and vegetables selling at premium prices. Tana Toraja in many ways would seem to parallel Baguio in the Philippines and Dalat in south Vietnam in terms of climate, highland culture, and produce marketing potential. Villagers seem eager and willing to experiment. Although vegetable production is much less spectacular than tourist promotion, the benefits to the populace as a whole are undoubtedly more immediate and tangible.

In spite of the strategically misplaced bathrooms, erection of garish white and blue orientation signs ("This way to the stone graves") or the expenditure of huge sums on welcome gates, the flow of tourists to Tana Toraja seems bound to increase. Although government planning for tourist promotion has been almost entirely directed to the improvement of access to interesting locales and the provision of facilities for foreign guests, little or no effort has been invested in ameliorating the effects of the influx on local society. Perhaps the creation of a craft institute to gather, catalog and eventually sell woven sarongs, basketry or carvings in wood and bone might be suggested. The one handicraft store in the region engages in a very lucrative trade in items not at all representative of the breadth of Toraja artisanry. The stimulation of craft industries through the establishment of an institute or cooperative might also go far towards alleviating the underemployment problem in the towns and villages of Tana Toraja. Some responsibility also must be exercised in the appearance of tourists at death festivals. The burden of providing for such guests must fall upon the tourist agency or coordinating government office, not upon the already hard-pressed villagers. Exaggerated stories have recently appeared in the Makassar and Jakarta press stating that "accommodations for $200^{\prime \prime}$ have been readied at festival grounds. The accommodations, as we have seen, are prepared for family members of the deceased, not for 
foreign tourists. Finally, government-trained guides might be certified so as to protect the burial sites from defacement (already rampant at one locale) and to guarantee some accuracy in the explication of local culture.

In the field of education the hostility between government and church-sponsored educational institutions shows no sign of abatement in the near future. Rising school costs and a diminishing mission budget have combined, with government hostility towards Gereja Toraja schools to restrict educational opportunity further. Increasing numbers of students are faced wi.th ever more expensive registration and graduation fees and a diminishing corps of teachers. Pressed by financial as well as political difficulties the Gereja Toraja teachers' school in Makale closed its doors in 1971. The government teachers' college for primary school têachers has to date graduated five classes, not one member of which has received employment from the government. In the absence of any clear policy statement on the subject one must assume either gross administrative incompetence or a policy of sharply curtailing educational facilities in the rural areas. Many young 1968 graduates of the government teacher training college are today barefooted mothers in isolated homesteads.

Tandung Revisited, January 1972

Through a sheer curtain of late afternoon rain Puang Kepala and his retinue of bird-handlers and retainers daily made their way up the hillside path to his home at the close of another round of cockfighting. The daughters of ancestral serfs pounded hard into the wooden lessung (mortar), hulling rice grains with the ageless rhythms of Toraja daily 1ife. Down were thrust the bamboo poles, up they rebounded to be caught swiftly with the other hand. Hens scratched the soil for errant kerne1s, contesting each morse1. Soon the grain would be winnowed and clean, ready for the kurin cooking pot. Carp culled from the Puang's ricefields would soon be roasted in bamboo tubes, spiced with small peppers and wild herbs. Often the legs of defeated cocks provided the basis for the evening meal. When the cockfighting finally concluded Puang Kepala decided to move his office from the center of Makale town. The new official quarters were placed just at the edge of his most expansive ricefield by the roadside. "Now," the Kepala Lembang reflected, "I needn't go all the way into town each day. If my assistants need me they can quickly send a note up the trail to my house. If a citizen wishes to speak directly with me let him come up here to my living quarters." The Kepala Lembang rarely ventures into town these days unless his attendance is required at an official meeting or ceremony. Villagers now visit with him in his home or at the large granary. The bureaucratic civility of urban office has been supplanted by the formality of traditional social intercourse. In town, students and teachers, officials and merchants moved with ease about the lembang office, civil administration uniforms were used by all officials, and the general term "Pak" was applied to those employed within. Now, dressed in casual sarong and sandals the Kepala Lembang often reviews official matters under the shelter of his large granary. Petitioners, schoolteachers and students infrequently make their way to the home of the village head on matters that require urgent attention. Invariably addressed as "Puang," the scion of Makale nobility tends to the daily affairs of the people. 
